ISSN (print): 1698-6180. ISSN (online): 1886-7995

www.ucm.es/info/estratig/journal.htm

Journal of Iberian Geology 36 (2) 2010: 297-326

doi:10.5209/rev_JIGE.2010.v36.n2.13

\title{
A holistic approach to the palaeoecology of Las Hoyas Konservat-Lagerstätte (La Huérguina Formation, Lower Cretaceous, Iberian Ranges, Spain)
}

\author{
Una aproximación holística a la palaeoecología del Konservat- \\ Lagerstätte de Las Hoyas (Formación La Huérguina, Cretácico \\ Inferior, Cordillera Ibérica, España)
}

\author{
A.D. Buscalioni ${ }^{1}$, M.A. Fregenal-Martínez ${ }^{2}$ \\ ${ }^{1}$ Unidad de Paleontología, Departamento de Biología, Facultad de Ciencias, Universidad Autónoma de Madrid, c/ \\ Darwin 2, Campus Universitario de Cantoblanco,28049 Madrid, Spain.angela.delgado@uam.es \\ ${ }^{2}$ Departamento de Estratigrafía e Instituto de Geología Económica (UCM-CSIC) Facultad de Ciencias Geológicas, \\ Universidad Complutense de Madrid, c/ José Antonio Novais 2, 28040 Madrid, Spain.mariana@geo.ucm.es \\ Authors in alphabetical order
}

Received: 08/12/09 / Accepted: 30/06/10

\begin{abstract}
The Las Hoyas fossil site (Lower Cretaceous, Iberian Ranges, Spain) is a classic lacustrine Fossil-Lagerstätte that exemplifies the features predicted by the original concept of Konservat-Lagerstätten in relation to the quantity of remains, quality of preservation, completeness, and preservation by a combination of obrution, stagnation and, in this case, mainly bacterial sealing. Fossils are preserved in rhythmically laminated limestones deposited in a environment that underwent strong, climatically driven cyclical oscillations in water level within the framework of a seasonal, subtropical, regional-scale wetland. Extensive systematic layer-bylayer excavation and geological research have resulted in a comprehensive understanding of the stratigraphy and sedimentology of the locality and its regional palaeogeography. Two approaches have allowed the palaeoecology of the fossil association to be reconstructed. Firstly, autoecological reconstructions of the fossil groups are supplemented by palaeoenvironmental reconstructions based on the sedimentology. This considers taphonomic features and the ecological structure of the whole association, including vegetation and animals. The organization of the ecosystem resembles that of extant lentic ecosystems. It is dominated by obligate aquatic and amphibious organisms; facultative terrestrial organisms are scarce. Several lines of evidence from flora and fauna indicate strong seasonality and water stress. The second approach is dynamic and aims to unravel the information transferred to the fossil record about ecological dynamics and evolution by combining stratigraphical and palaeontological information and integrating this in a spatial and temporal framework. This analysis illustrates that Las Hoyas has a significant facies bias, reflecting alternating
\end{abstract}


wet and dry climatically controlled periods. The biotic response these wet and dry cycles produced a coupling of taphonomic and sedimentary processes that resulted in the characteristic cyclical arrangement of the stratigraphic and palaeontological record. Las Hoyas therefore represents a subtropical seasonal wetland impacted by cyclicity and ecological stress. This stress impeded shortterm ecological evolution and resulted in a stable ecosystem that lasted for thousands of years. The results of this study also have implications for the concept of Konservat-Lagerstätten and its limitations. Whereas the former approach considers Las Hoyas as a canon of minimally biased information (as it is a Konservat-Lagerstätte), the latter approach reveals the biased characteristics of the association. The study illustrates that although all Konservat-Lagerstätten share similar preservational mechanisms, the paleoecological information that contain may differ.

Keywords: Las Hoyas, Konservat-Lagerstätten, Lentic Ecosystem, Paleoecological Dynamics, Facies Bias, Sedimentary and Taphonomic Cyclicity, Seasonal Wetlands, Lower Cretaceous

\section{Resumen}

El yacimiento de Las Hoyas (Cretácico Inferior, Cordillera Ibérica, España) es un clásico Fossil-Lagerstätte lacustre que encaja perfectamente con los rasgos que predice el concepto de Konservat-Lagerstätte en lo relativo a la abundancia de restos, calidad de conservación, completitud y génesis del depósito debido a la combinación de factores relacionados con el enterramiento rápido, el estancamiento y, en el caso particular de Las Hoyas, el sellado bacteriano. Los fósiles se conservan en calizas finamente laminadas que fueron depositadas en un ambiente que estuvo sujeto a fuertes oscilaciones cíclicas en el nivel de agua, climáticamente reguladas, en el marco de un humedal estacional y subtropical de escala regional. Las profusas excavaciones sistemáticas realizadas capa a capa, y la investigación geológica han dado lugar a un profundo conocimiento de la estratigrafía y sedimentología de la localidad y de su paleogeografía regional. Una doble aproximación a la interpretación de las asociaciones fósiles ha permitido la reconstrucción paleoecológica de la localidad. La primera parte de las reconstrucciones autoecológicas de los grupos fósiles retroalimentadas por la reconstrucción paleoambiental basada en la sedimentología. En esta aproximación se consideran las características tafonómicas y la estructura ecológica de la asociación completa, incluyendo la ecología vegetal y animal. La organización del ecosistema sigue un patrón semejante al de los ecosistemas lénticos actuales. Este ecosistema se caracteriza por la dominancia de organismos acuáticos obligados y de categorías anfibias y por la escasez de formas facultativas terrestres. Hay evidencias diversas, en la flora y en la fauna, de estrategias ecológicas vinculadas a la fuerte estacionalidad y al estrés hídrico. La segunda aproximación es dinámica, y pretende desvelar la información transferida al registro fósil en cuanto a la dinámica ecológica y su evolución mediante la combinación de información proporcionada por datos estratigráficos y paleontológicos, de modo que los datos son interpretados en términos de su marco y significado espacial y temporal. Este análisis muestra que Las Hoyas tiene un sesgo significativo de facies (facies bias), reflejando la alternancia de periodos húmedos y áridos controlados climáticamente. La respuesta biótica a estos ciclos húmedos y áridos produjo un acoplamiento entre los procesos tafonómicos y sedimentarios que da lugar a una estructura cíclica del registro estratigráfico y paleontológico de Las Hoyas. Por consiguiente, Las Hoyas representa un humedal subtropical estacional regido por la ciclicidad y por el estrés ecológico. Dicho estrés impide una evolución ecológica a corta escala dando lugar a un ecosistema estable que debió durar miles de años. El resultado de este estudio tiene algunas implicaciones en el concepto de Konservat-Lagerstätten y en sus limitaciones. Mientras que bajo la primera aproximación Las Hoyas se consideraría canon de información con un sesgo mínimo, puesto que es un depósito de conservación excepcional, la segunda aproximación pone de manifiesto el sesgo presente en la asociación. Este estudio ilustra que aunque todos los Konservat-Lagerstätten comparten mecanismos de conservación similares, la información paleoecológica que contienen difiere entre ellos.

Palabras clave: Las Hoyas, Konservat-Lagerstätten, Ecosistemas Lénticos, Dinámica Paleocológica, Facies Bias, Ciclicidad sedimentaria y tafonómica, Humedales estacionales, Cretácico Inferior

\section{Introduction}

\section{Konservat-Lagerstätten deposits are distinguished} by the quality of preservation of soft-bodied organisms (Seilacher, 1990). Konservat-Lagerstattën have been considered as the "end member of a continuum" in the preservational spectrum (Allison and Briggs, 1991). Various factors and combinations thereof can be involved in the genesis of any deposit, but exceptional deposits have been explained within the framework of three parameters: obrution, stagnation and bacterial sealing. This background, provided by Seilacher et al. (1985), thus offers a broad, simple classification. Konservat-Lagerstattën are usually interpreted as having resulted from the presence of specific palaeoecological and palaeoenvironmental factors, such as the presence of oxyclines or haloclines, biostratinomic factors involving rapid burial or factors related to necrolysis, such as the role of bacterial mats in slowing the rate of degradation of soft tissues and their authigenic replacement. Influenced by Seilacher's model most studies use the preservational potential of a particular environment (e.g., anoxic bottom, early phosphatization, rapid burial, etc.) to explain why fossils are exceptionally well preserved (see for instance Stinnesbeck et 
al. 2005 for the Late Cretaceous outcrop of El Rosario in Mexico). Concerning the relative abundance and absence of the preserved taxa, the composition of fossil assemblages is explained in ecological terms (environmental affinities and preferred habitats of species) rather than as taphonomic biases (see as an example Palci et al., 2008 for the Kolmen, Slovenia Cenomanian Lagerstätte).

For many decades Konservat-Lagerstätten have been considered a canon with maximum information, exceptional places where palaeobiological information has been somehow frozen, the succession of singular "catastrophic events" of mass mortality being the commonest explanation for these exceptional deposits (Shipman, 1975).

Konservat-Lagerstätten have revealed the existence of organisms that never fossilize under other conditions, and the anatomical details of organic structures that would otherwise remain unknown; in summary they have provided specialists with abundant key evolutionary biological data. Little would be known about the early evolutionary stages of marine life if the Burgess Shale and Chengjiang did not exist. They may be thought of as windows onto the fossil record, through which the best approaches to the studying the Earth's biological past can be pursued.

Assuming all these arguments are correct, it could also be argued that a realistic model of the representativity of this type of fossiliferous deposit with respect to palaeoecological aspects, among others, is methodologically handicapped. In other words, the Konservat-Lagerstätte model has become associated with a static or frozen view of palaeoecology that neglects the temporal sequence of events. In contrast a more dynamic perspective of a more holistic view, of the quality (i.e., preservation and bias) of the fossil record has been focused particularly in the marine realm, and structured within the sequence stratigraphic perspective (Holland, 2000). The advantage of this approach is that it accommodates many of the biases of the fossil record that vary over time and between environments.

It is not known yet if all of the Konservat-Lagerstätten are "palaeoecological windows" as they are for the studies on past biodiversity. It remains unclear what kind of palaeoecological information is transferred to the fossil record,that is, whether the Lagerstattën preserve their original dynamics and palaeoecological structure, and to what extent any bias is common to all Konservat-Lagerstätten.

Las Hoyas is a well-known Barremian (Lower Cretaceous) continental Konservat-Lagestätten, acknowledged as one of the most important Lower Cretaceous Lagersttäten in the world (Sanz et al., 2001). It is located at the Serranía de Cuenca (Iberian Ranges, east-central Spain) and occurs within the La Huérguina Limestone Formation. Since it was discovered in 1985 it has yielded several thousand ichnofossils and body fossils, the latter including Bacteria, Fungi, Protista (Foraminifera), Algae, and a wide spectrum of Plant and Animal phyla (Buscalioni et al., 2008; Fregenal-Martínez and Buscalioni, 2009, see below). It is especially well known as probably the best Mesozoic locality for fossil insects (Martínez-Delclós et al., 2004). The locality has provided palaeontologists with information critical to understanding the early radiation of birds and the development of flight (Sanz et al., 2002). It has also yielded significant information on the evolution and life habits of other organisms. For instance, articulated Characeae with their vegetative apparatus preserved were described first from Las Hoyas (Martin-Closas and Diéguez, 1998). The enigmatic Montsechia vidali has been interpreted as being an aquatic angiosperm on the basis of its ultrastructural preservation (Daviero-Gómez et al., 2006). The replacement of "holostean" by early teleostean faunas may be documented at Las Hoyas (Poyato-Ariza, 2005). Some of the most significant discoveries relate to the anatomy of the albanerpetontid Celtedens (McGowan and Evans, 1995), and the early evolution of Aves, for example the presence of a pygostile in Iberomesornis romeralli. The earliest known alula was recorded in Eoaulavis (Sanz et al., 1996; Sanz et al., 2002) (see http://www.yacimientolashoyas.es for a list of cases and references).

Most of the fossils are fully articulated (excluding macrophytes) and many preserve soft tissues, and organic patterns and structures rarely found in the fossil record: patterns of colouring, nerviation, gut tracts, and ommatidium of insects, stomach contents and muscles of fishes, skin and integumentary tissues of such as frogs, salamanders, lizards, crocodiles and dinosaurs.

The sedimentary succession of Las Hoyas is a continuous, cyclical accumulation of finely laminated limestones deposited in an area that on a regional-scale was a wetland environment, strongly influenced by subtropical, seasonal climatic conditions.

The comprehensive palaeontological and stratigraphical records of Las Hoyas, and the large amount of data retrieved from many years of layer-by-layer excavation, have allowed us to adopt a dual approach to reconstructing the palaeoecology of the fossil assemblage. The goals of the current study are therefore two-fold. The first is to perform a palaeoecological analysis based on sedimentological data, the taphonomic features of the fossil association, and the recorded biota. Since Las Hoyas is a Konservat-Lagerstätte, this analysis will consider the entire fossiliferous lithosome as a unique, minimally bi- 
ased, taphonomic unit. The second goal is to determine whether palaeoecological information can be interpreted in the context of ecological dynamics, especially evolutionary dynamics, by analyzing Las Hoyas in the actual temporal and spatial framework provided by its stratigraphic record. This approach aims to be the starting point for advances in the concepts and methodologies of palaeoecology, encouraging analyses of dynamics, while questioning some traditional assumptions in this area of research.

In the light of the conclusions obtained from the palaeoecological analysis of Las Hoyas the value and meaning of Konservat-Lagerstätten from the palaeoecological perspectiveis also revised.

\section{Geological setting}

The Serranía de Cuenca is part of the Iberian Ranges, a NW-SE oriented mountain chain that covers an extensive area in the eastern half of the Iberian Peninsula and was generated by the tectonic inversion of the Iberian Basin. The Iberian Basin was an intracratonic extensional basin formed during the Late Permian-Early Triassic that remained active throughout the Mesozoic until the Alpine Orogeny.

During the Late Jurassic-Early Cretaceous the Iberian Basin experienced a rifting phase related to the opening of the central Atlantic and the rotation of the Iberian Plate (Salas and Casas, 1993). Four palaeogeographic domains have been defined for the Early Cretaceous of the Iberian Basin (Soria et al., 2000): Cameros, Central Iberian, Maestrazgo and South-western Iberian (Fig. 1A). Extensional tectonics divided each domain into many welldifferentiated subbasins of graben and half-graben type.

The South-western Iberian Domain was limited by extensional fault systems running NW-SE (Vilas et al., 1982, 1983, Mas et al., 1982), with associated NE-SW systems of transfer faults that accommodated differences in extension rates.

The NE-SW Landete-Teruel transfer fault divides the South-western Iberian Domain into the Serranía de Cuenca and Valencia Basins. The Serranía de Cuenca Basin was in turn divided by the NW-SE extensional Hesperic fault to form two subsiding troughs (Uña-Las Hoyas and La Huérguina). The Uña-Las Hoyas Trough is composed of at least five small subbasins: Uña, Buenache, Los Aliagares, Las Hoyas and La Cierva (Fig. 1B).

Barremian sedimentation in the Serranía de Cuenca occurred under continental environmental conditions and no direct marine influence is observed (Poyato-Ariza et al., 1998). Marine influence is restricted to the Valencia
Basin which was bounded by the Tethys Sea at its eastern edge (Mas et al., 1982).

The climate of this area has always been considered to be seasonal subtropical with alternating wet and dry seasons. This interpretation is based on several sources of proxy climate data. Ziegler et al. (1983) performed a palaeogeographical and palaeoclimatic reconstruction and placed this area of the Western Tethys at the dry, divergent subtropical zone at a latitude of $25-30^{\circ} \mathrm{N}$. Ziegler et al. (1987), on the basis of palaeobotanical data, proposed that seasonality occurred in tropical and subtropical areas, and a seasonal warm and semi-arid subtropical climate was assumed for the Iberian Plate during the Lower Cretaceous. Haywood et al. (2004) developed a model for Barremian Wealden climates of Western Europe using a Limited Area Model, which confirmed strong biannual seasonality of temperature, with mean cold-month temperatures of $4-8^{\circ} \mathrm{C}$, and mean warm-month temperatures of $36-40^{\circ} \mathrm{C}$. However, the model unexpectedly predicts an average precipitation rate of 4-8 $\mathrm{mm} /$ day for any one month, and more than $16 \mathrm{~mm} /$ day during the cold season. The model-predicted moisture budget results in very high evaporation rates, which greatly reduces moisture availability at ground level, thus accounting for the proxy data indicating dry conditions. Successive facies analyses of the Barremian deposits in different areas of the Serranía de Cuenca Basin have repeatedly shown sedimentological evidence of seasonality and highlighted climate as a extremely significant allocyclic control of sedimentation (Gierlowski-Kordesch et al., 1991, Gómez-Fernández and Meléndez 1991, Fregenal-Martínez and Meléndez, 1993, Fregenal-Martínez 1998, Fregenal-Martínez and Meléndez, 2000).

In the Serranía de Cuenca, Barremian sediments overlie Bathonian (Middle Jurassic) marine limestone unconformably (Fig. 1B); the latter underwent strong karstification during the Upper Jurassic and even during continental Early Cretaceous sedimentation.

Barremian continental deposits form two lithostratigraphic units linked by a lateral facies change: El Collado Sandstones Fm and La Huérguina Limestones Fm (Vilas et al., 1982).

The Uña-Las Hoyas Trough exhibits little El Collado Fm, being filled mainly by deposits of the La Huérguina Fm. The thickest succession of the La Huérguina Fm occurs in the Las Hoyas Subbasin, which was infilled by almost $400 \mathrm{~m}$ of distal alluvial and palustrine-lacustrine deposits (Fregenal-Martínez 1998, Fregenal-Martínez and Meléndez, 2000). The sedimentary record of Las Hoyas has been divided into four sequences (Fig. 1C) separated by local unconformities or paraconformities and named 

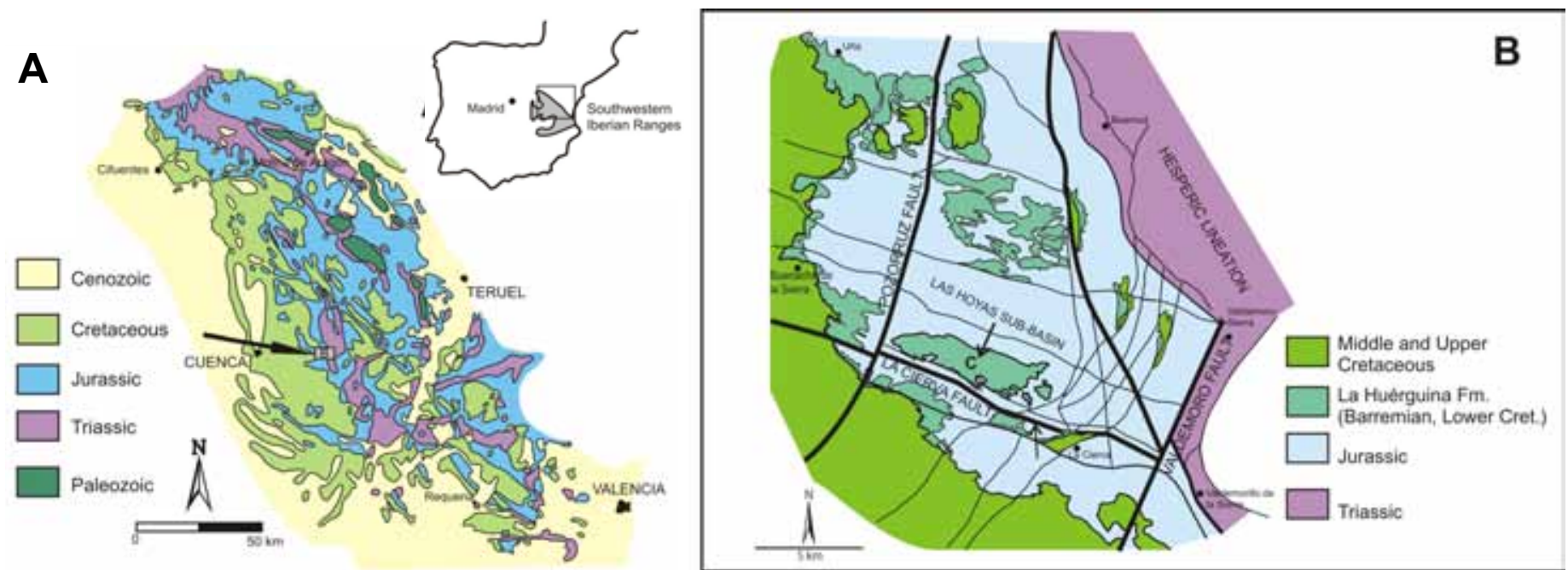

Fig. 1.-A. Location and general geological map of the Southwestern Iberian Ranges. B. Simplified geological map of Las Hoyas area. C. Detailed geological map of Las Hoyas sub-basin showing the position of Las Hoyas fossil site.

Fig. 1.-A. Localización y mapa geológico general de la Cordillera Ibérica Suroccidental. B. Mapa geológico simplificado del entorno de Las Hoyas. C. Mapa geológico detallado de la cubeta de Las Hoyas en el que se muestra la posición del yacimiento de Las Hoyas.

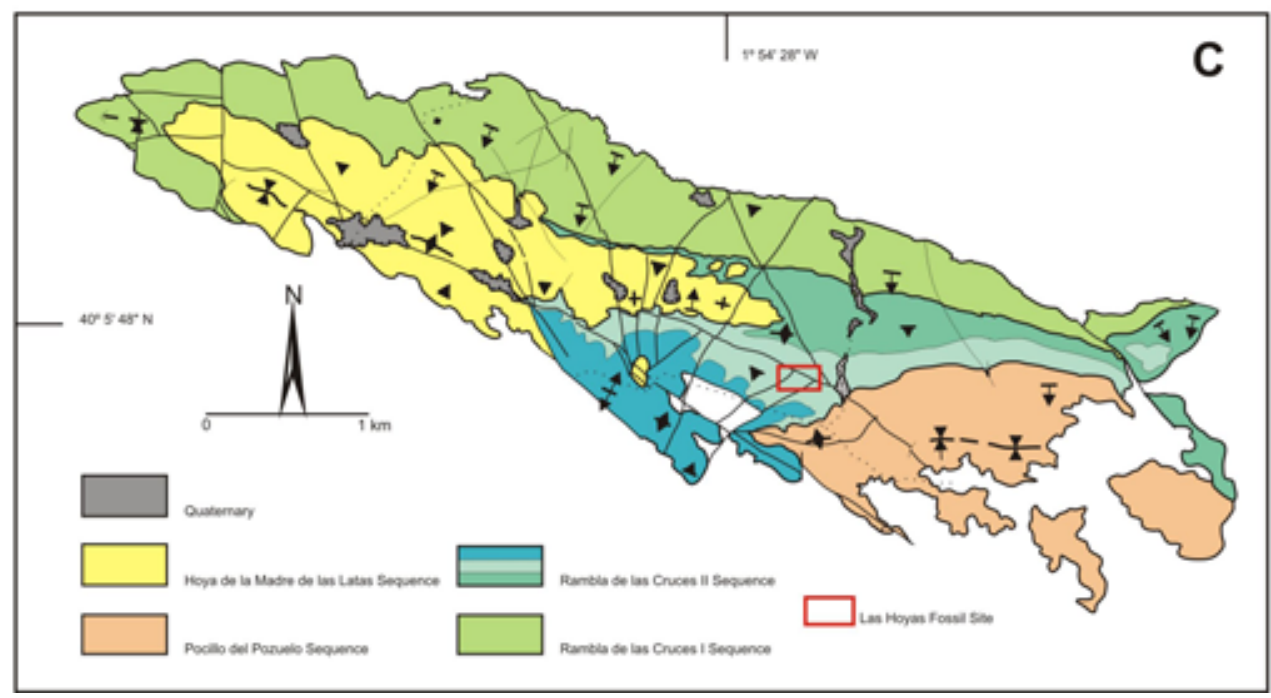

informally in ascending order as Rambla de Las Cruces I, Rambla de Las Cruces II, Pocillo del Pozuelo and Hoya de la Madre de Las Latas (Fregenal-Martínez, 1998, Fregenal-Martínez and Meléndez, 2000).

The fossil-bearing rhythmically laminated limestones of the Las Hoyas Konservat-Lagerstätte occur in the Rambla de Las Cruces II Sequence, which is entirely composed of carbonates and characterized by the dominance of palustrine-lacustrine facies over distal alluvial and flood-plain facies.

\section{Conceptual and methodological framework}

The two objectives proposed in this work relate to two distinct conceptual frameworks. The results will illustrate that the two approaches are complementary.

The first approach assumes a "static" palaeoecological interpretation, and is based on sedimentology and supplemented by palaeobiology and taphonomy. It enhances the functional relationships and the congruence among (i) the palaeoenvironmental hypothesis (addressed from the sedimentological analyses that establish the abiotic framework of the ecosystem), (ii) the taphonomic features of fossils (in terms of preservation of each fossil); and (iii) the relative abundance of fossils. The pattern of abundance refers herein not to the taxa themselves (as is common in this kind of study), but on the ecological categories that, according to the palaeoenvironmental hypothesis, should reflect a predicted structure. The use of ecological categories avoids the problem of rarity in species due to preservation, and furnishes the strong lines of the ecological structure, and it is thus likely to be a robust method of analysis. Epistemologically, the combination of the selected information about sedimentology, taphonomy and palaeobiology thus describes: 1) the potential for representativity, i.e., the fidelity of the composition of the palaeoecosystem, 2) the ecological dominance of the group of species that regulate the ecosystem, and 3) outstanding and significant palaeoecological processes that may explain the genesis of the deposit 
and its potential biases.

The second approach is "dynamic" in that it interprets the taphonomic assemblages with respect to environment and time. In other words, the significance of the taphonomic data including their distribution within the fossiliferous lithosome will be explained in terms of the sedimentological meaning (environment) of the various facies that host each different taphonomic assemblage, and the stratigraphic architecture that the facies sequences display (sedimentary evolution over time).

Dynamic reading with respect to the environment will provide key evidence about what Holland (2000) identified "facies bias", highlighting the environmental signal that controls differences in fossil abundance and richness. For this purpose the fossil associations present in all the facies have been compared.

Dynamic reading with respect to time will reveal the extent to which the structures of the fossil and sedimentary records are determined by the palaeoecological dynamics and whether there is an architectural taphonomic and sedimentary coupling. To this end, the succession of communities developed during every sedimentary sequence has been compared.

The taphonomic analysis performed to enable the dynamic reading includes the following criteria: the degree of demicity ( $v s$. ademic) and autochthony (vs. allochthony) of the association (Fernandez-López, 1989). Demic is a biological criterion, and is applied to those fossils that come from organisms that left ichnological traces or body parts, and/or that died in the same environment where they lived or that was their original habitat. Allochthonous is a taphonomic criterion applied to fossils that have been transported out of the place where the organism died or left any part. Whereas autochthonous refers to fossil that havebeen preserved where the organism died or left any part, no matter where they lived. For instance, in Solnhofen the famous horseshoe-crab fossil that left its trail before dying should be treated, applying those criteria, as ademic and autochthonous. This is the reason why Fernandez-López $(1989,1991)$ suggested that each criterion should be considered independently to maximize its heuristic potential, and herein we follow his criteria (i.e., demicity and autochthony). The spatial fidelity concept used by Behrensmeyer et al. (2000) combines both sets of criteria (biological and taphonomic) without any explicit denomination of the weighting given to either, but the authors emphasised its relevance for understanding the preservational processes. Finally, this dynamic approach also gives a better appreciation of what has been called temporal resolution (Behrensmeyer et al., 2000), which is the finest scale temporal category into which the taphonomic association can be confidently assigned. Linked to temporal resolution is an evaluation of time-averaging (from virtually zero to millions of years), as the period of time represented by the biological components that comprise any fossil assemblage.

\subsection{Data sampling and analyses}

To deal with biases the primary requisite is to collect high quality data using appropriate fieldwork strategies. The database has been constructed using a systematic layer-by-layer sampling method. For each layer, the size and total number of specimens were first determined. Orientation was occasionally measured because Las Hoyas fossils are randomly distributed. Layer-by-layer excavation of square areas of $25 \mathrm{~m}^{2}$ on average was carried out (Fig. 2). A total volume of more than $3000 \mathrm{~m}^{3}$ rocks was excavated.

To address the palaeobiological framework we used the complete taxonomic list of Las Hoyas, which includes information from systematic and random sampling methodologies. The taxonomic list is periodically improved by taxonomic revision carried out by specialists.

To address the sedimentary framework, the laminated limestones were exhaustively and continuously sampled. These limestones have a homogeneous appearance in the field and facies successions and associations have to be reconstructed under a petrographic microscope (Fig. 3). To this end, sampling covers the entire thickness of the excavated areas, and thin sections of rock sample were used for the microscopic description. Samples were taken while palaeontological excavation was being performed, in such a way that the fossil content of the sampled layers was always known. Herein we present the results of five years of excavations in which five contiguous areas were systematically sampled, each area being given the name of a colour (Figs. 2 and 4): 1) pink 1996, 2) pink 1998, 3) lower black, 4) upper black and 5) lowermost black. The sampled laminites were almost one metre thick in total and were composed of three elemental sequences (Fig. 4).

The raw data summarize the total number of fossils discovered (see Table 1 and Appendix 1). "N" takes into account only body fossils, although in the discussion other some relevant fossils are considered qualitatively, such as "worms", coprolites and ichnofossils, that have not been quantitatively analysed because the sampling technique and taxonomical identifications progressively improved, and thus data accuracy differed slightly between areas. Consequently, neither plant remains nor other trace fossils such as coprolites and ichnofossils are included in the account provided in Table 1. 


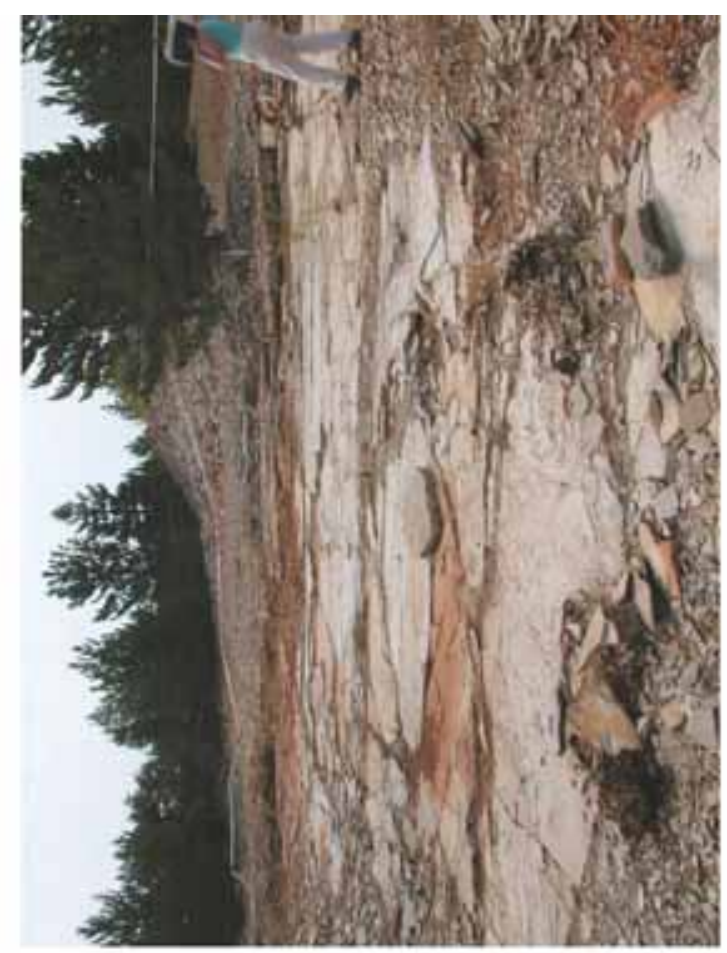

山

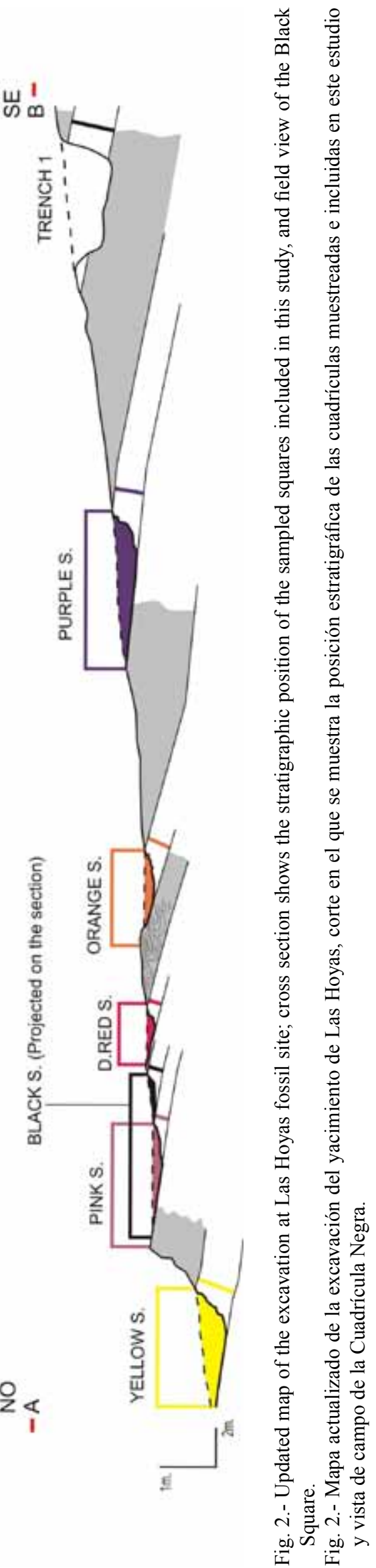



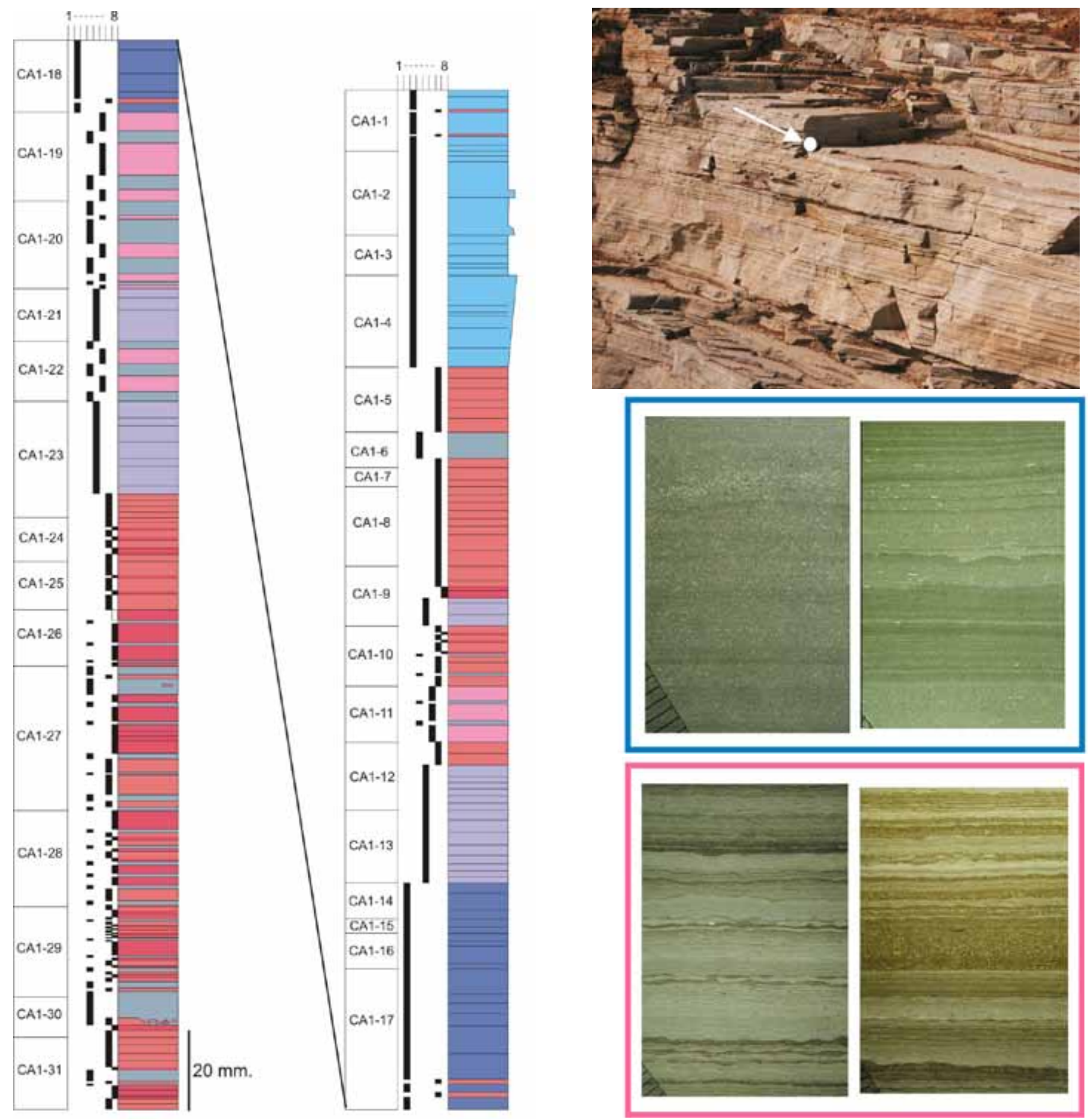

Fig. 3.- Close-up field view of laminated facies (white arrow points to a 2 euro coin for scale); reconstructed stratigraphic succession, obtained from thin sections, after a continuous layer by layer sampling. Up to eight different microfacies have been recognized numbered from 1 to 8 in the $\log$ at left and also represented by colors that range from deep blue to deep pink. The succession displays cyclical alternation of facies deposited during periods of wet (blue and bluish colored intervals) and dry (pink and pinkish colored intervals) environmental conditions. Two examples of each type of facies under the petrographic microscope are also shown, wet inside the blue framework and dry inside the pink framework. Scale division: $1 \mathrm{~mm}$.

Fig. 3.- Vista de detalle en campo de las facies laminadas (la flecha blanca señala una moneda de 2 euros como escala); sucesión estratigráfica reconstruida obtenida a partir de láminas delgadas realizadas de un muestreo de campo continuo capa a capa. Se han reconocido hasta ocho microfacies diferentes que aparecen numeradas de 1 a 8 en la columna de la izquierda y que están también representadas por una gama de colores que va del azul intenso al rosa intenso como extremos. La sucesión muestra la alternancia cíclica de facies depositadas durante periodos con condiciones ambientales húmedas (intervalos coloreados en tonos azulados) y áridas (intervalos coloreados en tonos rosados). También se incluyen dos ejemplos de cada conjunto de facies a escala microscópica, las húmedas dentro del marco azul y las áridas dentro del marco rosa. 


\section{Characterization of Las Hoyas Konservat- Lagerstätte and its ecosystem:"static" approach}

\subsection{Paleoenvironmental reconstruction and sedimentol- ogy of Las Hoyas deposits}

The picture that emerges when palaeogeographical, stratigraphical and sedimentological data are analyzed in terms of a palaeoenvironmental reconstruction for the Barremian in the Serranía de Cuenca is that of an extensive subtropical (seasonal, winter wet), continental (freshwater) wetland system, dominated by carbonate sedimentation that overlay a low-relief karstic terrain. A flat, smooth, topography with localized ridges of Jurassic limestones at the edge of the sub-basins at the time of deposition was the general landscape. Consequently, the watershed, and source areas of sediments would have been mostly composed of carbonates.

The groundwater and surface waters draining the basin would therefore have contained a high concentration of dissolved calcium carbonate that enhanced the pedogenic and biological production of carbonate and maintained basic $\mathrm{pH}$ conditions in ephemeral and permanent water bodies. The wetland landscape comprises the typical environmental mosaic within these depositional systems: alluvial plains, marshy and swampy palustrine plains, different types of channels, sloughs, ponds and shallow permanent lakes.

Strong seasonal differences in landscape geomorphology reflect water availability, which was greater during the wet season. During this season ponds and lakes had their highest water levels, palustrine and alluvial plains were flooded and all channels were active. During the dry season most ponds dried out, lakes had low water levels, alluvial and palustrine plains were subaerially exposed and dominated by pedogenic processes, and ephemeral channels remained inactive.

As in modern subtropical wetlands fire was an active element in these environments, and charcoal is abundant in different facies. Charcoal in flash-flood deposits is of particular significance, and suggests an association between fire and strong seasonal storms followed by flooding. Blacked pebbles and charcoal associated with palustrine deposits indicate that the other common cause of fire in these environments was spontaneous combustion with inorganic-rich palustrine soils.

The paleogeographical distribution of the different elements of the environmental mosaic reflected local conditions and each sub-basin had its own specific set of environments, e.g., permanently flooded wetlands and lakes located in specific depocentres. The type of channels var- ied depending on the proximity to watersheds and source areas, and palustrine and pedogenic environments were associated with non-subsiding areas, such as sub-basin margins.

The fossiliferous sediments of Las Hoyas are finely laminated limestones composed almost entirely of calcium carbonate with a small fraction of clays and organic matter. These sediments accumulated in a hard water, periphyton-dominated wetland, which was covered by thick microbial mats, and underwent strong, climatically driven cyclical oscillations of the water level.

Despite the homogeneous field appearance of laminated facies, two alternating facies associations, and several transitional facies between them have been distinguished petrographically (Fig. 3).

The first association is the result of sedimentation by traction and decantation of allochthonous detrital carbonate particles and vegetal debris, chemical and bio-induced precipitation of calcium carbonate, and accumulation of thin microbial mats (Fig. 3, blue framed). These were deposited during seasonal flooding and longer-term wet periods during which high water levels favoured more lacustrine conditions.

The second association reflects the autochthonous production of carbonate linked to the growth of microbial mats that grew massively during dry periods when the water column was drastically reduced to probably just a few centimetres deep. Microbial mats and laminae of very fine detrital carbonate sediments with debris of plants and other organic remains were transported during occasional floods and form sediments deposited during dry periods (Fig. 3, pink framed). The association of dry period sediments with dinosaur and crocodile trails and isolated tetrapod tracks, as well as the sparse presence of desiccation cracks, are indicative of extreme low water levels, and support strong water level oscillations between wet and dry periods. Preliminary geochemical data from carbon and oxygen isotopes (Talbot et al., 1995) suggest that Las Hoyas sediments were derived from karstic water. Therefore, the groundwater might have maintained a thin persistent water cover, or at least a certain level of humidity in the sediments, thereby avoiding frequent complete desiccation. Some drought events are implied by the presence of desiccation cracks.

Preservation of laminated sediments requires a special set of environmental conditions; in particular destruction of lamination, mainly by bioturbation, must be avoided. Anoxia is often invoked to explain such conditions. Since thermal or chemical water stratification processes are unlikely to occur in shallow freshwater subtropical lakes and wetlands, it has been hypothesized that the warm 


\begin{tabular}{|c|c|c|c|c|c|c|c|c|c|c|c|c|c|c|c|c|c|c|c|c|c|c|c|c|c|c|c|c|}
\hline SL & $\mathbf{F}$ & $\mathbf{Q}$ & NAS & I & $\mathrm{C}$ & W & O & NF & NC & NI & NB & $\mathbf{A}$ & B & $\mathrm{C}$ & D & $\mathbf{E}$ & $\mathbf{F}$ & G & $\mathbf{H}$ & I & 1 & 2 & 3 & 4 & 5 & 6 & 7 & 8 \\
\hline $\mathrm{NgI02R}$ & $\mathrm{D}$ & 3 & 59 & $\mathrm{~N}$ & $\mathrm{Y}$ & $\mathrm{N}$ & $\mathrm{N}$ & 5 & 46 & 9 & 1 & 45 & 0 & 0 & 2 & 7 & 0 & 0 & 0 & 0 & 0 & 0 & 0 & 0 & 0 & 5 & 0 & 0 \\
\hline $\mathrm{NgI} 2 \mathrm{~A}$ & W & 2 & 1 & $\mathrm{~N}$ & $\mathrm{~N}$ & $\mathrm{~N}$ & $\mathrm{~N}$ & 0 & 0 & 1 & 0 & 0 & 0 & 0 & 0 & 0 & 1 & 0 & 0 & 0 & 0 & 0 & 0 & 0 & 0 & 0 & 0 & 0 \\
\hline NgI6A & W & 2 & 1 & $\mathrm{~N}$ & $\mathrm{~N}$ & $\mathrm{~N}$ & $\mathrm{~N}$ & 0 & 0 & 1 & 0 & 0 & 0 & 0 & 0 & 0 & 0 & 1 & 0 & 0 & 0 & 0 & 0 & 0 & 0 & 0 & 0 & 0 \\
\hline $\mathrm{NgI7A}$ & W & 2 & 7 & $\mathrm{~N}$ & $\mathrm{~N}$ & $\mathrm{~N}$ & $\mathrm{~N}$ & 4 & 0 & 3 & 0 & 0 & 0 & 0 & 1 & 0 & 1 & 0 & 0 & 0 & 0 & 0 & 0 & 0 & 0 & 4 & 0 & 0 \\
\hline NgI9A & W & 2 & 1 & $\mathrm{~N}$ & $\mathrm{~N}$ & $\mathrm{~N}$ & $\mathrm{~N}$ & 0 & 0 & 1 & 0 & 0 & 0 & 0 & 0 & 1 & 0 & 0 & 0 & 0 & 0 & 0 & 0 & 0 & 0 & 0 & 0 & 0 \\
\hline NgI10R & $\mathrm{D}$ & 2 & 47 & $\mathrm{~N}$ & $\mathrm{Y}$ & $\mathrm{N}$ & $\mathrm{N}$ & 46 & 1 & 0 & 0 & 1 & 0 & 0 & 0 & 0 & 0 & 0 & 0 & 0 & 46 & 0 & 0 & 0 & 0 & 0 & 0 & 0 \\
\hline NgI11R & $\mathrm{D}$ & 2 & 1 & $\mathrm{~N}$ & $\mathrm{Y}$ & $\mathrm{N}$ & $\mathrm{N}$ & 1 & 0 & 0 & 0 & 0 & 0 & 0 & 0 & 0 & 0 & 0 & 0 & 0 & 0 & 0 & 0 & 0 & 1 & 0 & 0 & 0 \\
\hline NgI12R & $\mathrm{D}$ & 2 & 31 & $\mathrm{Y}$ & $\mathrm{Y}$ & $\mathrm{N}$ & $\mathrm{N}$ & 19 & 8 & 4 & 0 & 8 & 0 & 0 & 2 & 1 & 0 & 0 & 0 & 0 & 19 & 0 & 0 & 0 & 0 & 0 & 0 & 0 \\
\hline NgI1314R & $\mathrm{D}$ & 2 & 3 & $\mathrm{~N}$ & $\mathrm{~N}$ & $\mathrm{~N}$ & $\mathrm{~N}$ & 2 & 0 & 1 & 0 & 0 & 0 & 0 & 0 & 0 & 0 & 0 & 0 & 0 & 2 & 0 & 0 & 0 & 0 & 0 & 0 & 0 \\
\hline NgI1415R & $\mathrm{D}$ & 2 & 30 & $\mathrm{~N}$ & $\mathrm{Y}$ & $\mathrm{Y}$ & $\mathrm{N}$ & 3 & 6 & 4 & 0 & 5 & 0 & 1 & 0 & 0 & 0 & 0 & 0 & 0 & 2 & 0 & 0 & 1 & 0 & 0 & 0 & 0 \\
\hline $\mathrm{NgS} 1 \mathrm{~A}$ & W & 3 & 0 & $\mathrm{~N}$ & $\mathrm{Y}$ & $\mathrm{N}$ & $\mathrm{N}$ & 0 & 0 & 0 & 0 & 0 & 0 & 0 & 0 & 0 & 0 & 0 & 0 & 0 & 0 & 0 & 0 & 0 & 0 & 0 & 0 & 0 \\
\hline $\mathrm{NgS} 2 \mathrm{~A}$ & W & 3 & 1 & $\mathrm{~N}$ & $\mathrm{Y}$ & $\mathrm{N}$ & $\mathrm{N}$ & 1 & 0 & 0 & 0 & 0 & 0 & 0 & 0 & 0 & 0 & 0 & 0 & 0 & 0 & 0 & 0 & 0 & 0 & 0 & 0 & 0 \\
\hline $\mathrm{NgS} 4 \mathrm{~A}$ & W & 3 & 2 & $\mathrm{~N}$ & $\mathrm{~N}$ & $\mathrm{~N}$ & $\mathrm{~N}$ & 0 & 0 & 2 & 0 & 0 & 0 & 0 & 0 & 2 & 0 & 0 & 0 & 0 & 0 & 0 & 0 & 0 & 0 & 0 & 0 & 0 \\
\hline NgS5R & $\mathrm{D}$ & 3 & 5 & $\mathrm{~N}$ & $\mathrm{Y}$ & $\mathrm{N}$ & $\mathrm{N}$ & 1 & 2 & 1 & 0 & 2 & 0 & 0 & 0 & 0 & 0 & 0 & 1 & 0 & 1 & 0 & 0 & 0 & 0 & 0 & 0 & 0 \\
\hline NgS7R & $\mathrm{D}$ & 3 & 3 & $\mathrm{~N}$ & $\mathrm{Y}$ & $\mathrm{Y}$ & $\mathrm{N}$ & 0 & 0 & 2 & 0 & 0 & 0 & 0 & 1 & 0 & 0 & 0 & 0 & 0 & 0 & 0 & 0 & 0 & 0 & 0 & 0 & 0 \\
\hline $\mathrm{NgS} 8 \mathrm{R}$ & $\mathrm{D}$ & 3 & 2 & $\mathrm{~N}$ & $\mathrm{~N}$ & $\mathrm{~N}$ & $\mathrm{~N}$ & 0 & 0 & 2 & 0 & 0 & 0 & 0 & 0 & 2 & 0 & 0 & 0 & 0 & 0 & 0 & 0 & 0 & 0 & 0 & 0 & 0 \\
\hline $\mathrm{NgS9R}$ & $\mathrm{D}$ & 3 & 41 & $\mathrm{~N}$ & $\mathrm{~N}$ & $\mathrm{Y}$ & $\mathrm{N}$ & 4 & 2 & 29 & 1 & 1 & 0 & 0 & 3 & 19 & 2 & 1 & 1 & 2 & 1 & 0 & 0 & 1 & 0 & 2 & 0 & 0 \\
\hline NgS1012A & W & 2 & 3 & $\mathrm{~N}$ & $\mathrm{Y}$ & $\mathrm{N}$ & $\mathrm{N}$ & 1 & 0 & 2 & 0 & 0 & 0 & 0 & 1 & 0 & 0 & 1 & 0 & 0 & 0 & 0 & 0 & 0 & 0 & 0 & 0 & 0 \\
\hline $\mathrm{NgS14A}$ & W & 2 & 1 & $\mathrm{~N}$ & $\mathrm{~N}$ & $\mathrm{~N}$ & $\mathrm{~N}$ & 0 & 0 & 1 & 0 & 0 & 0 & 0 & 0 & 1 & 0 & 0 & 0 & 0 & 0 & 0 & 0 & 0 & 0 & 0 & 0 & 0 \\
\hline NSC1A & W & 2 & 0 & $\mathrm{~N}$ & $\mathrm{~N}$ & $\mathrm{~N}$ & $\mathrm{~N}$ & 0 & 0 & 0 & 0 & 0 & 0 & 0 & 0 & 0 & 0 & 0 & 0 & 0 & 0 & 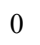 & 0 & 0 & 0 & 0 & 0 & 0 \\
\hline NSC3A & W & 2 & 2 & $\mathrm{~N}$ & $\mathrm{~N}$ & $\mathrm{~N}$ & $\mathrm{~N}$ & 2 & 0 & 0 & 0 & 0 & 0 & 0 & 0 & 0 & 0 & 0 & 0 & 0 & 1 & 0 & 0 & 0 & 0 & . & 0 & 0 \\
\hline $\mathrm{NSC} 45 \mathrm{~A}$ & W & 2 & 1 & $\mathrm{~N}$ & $\mathrm{~N}$ & $\mathrm{~N}$ & $\mathrm{~N}$ & 0 & 0 & 1 & 0 & 0 & 0 & 0 & 0 & 1 & 0 & 0 & 0 & 0 & 0 & 0 & 0 & 0 & 0 & 0 & 0 & 0 \\
\hline NSC6R & $\mathrm{D}$ & 2 & 108 & $\mathrm{~N}$ & $\mathrm{~N}$ & $\mathrm{~N}$ & $\mathrm{~N}$ & 101 & 6 & 1 & 0 & 6 & 0 & 0 & 0 & 0 & 0 & 0 & 0 & 0 & 100 & 0 & 0 & 0 & 0 & 0 & 0 & 1 \\
\hline NSC7R & $\mathrm{D}$ & 2 & 22 & $\mathrm{~N}$ & $\mathrm{Y}$ & $\mathrm{Y}$ & $\mathrm{Y}$ & 13 & 4 & 2 & 0 & 4 & 0 & 0 & 2 & 0 & 0 & 0 & 0 & 0 & 13 & 0 & 0 & 0 & 0 & 0 & 0 & 0 \\
\hline NSC8R & $\mathrm{D}$ & 2 & 12 & $\mathrm{Y}$ & $\mathrm{N}$ & $\mathrm{N}$ & $\mathrm{N}$ & 3 & 0 & 0 & 0 & 0 & 0 & 0 & 0 & 0 & 0 & 0 & 0 & 0 & 1 & 0 & 0 & 2 & 0 & 0 & 0 & 0 \\
\hline NSC910R & $\mathrm{D}$ & 2 & 51 & $\mathrm{Y}$ & $\mathrm{Y}$ & $\mathrm{N}$ & $\mathrm{Y}$ & 4 & 6 & 3 & 0 & 2 & 0 & 1 & 1 & 0 & 0 & 0 & 0 & 1 & 4 & . & 0 & 0 & 0 & 0 & 0 & 0 \\
\hline NSC11A & W & 1 & 2 & $\mathrm{~N}$ & $\mathrm{Y}$ & $\mathrm{N}$ & $\mathrm{N}$ & 2 & 0 & 0 & 0 & 0 & 0 & 0 & 0 & 0 & 0 & 0 & 0 & 0 & 0 & 0 & 0 & 0 & 0 & 1 & 1 & 0 \\
\hline RS0198A & W & 1 & 4 & $\mathrm{~N}$ & $\mathrm{~N}$ & $\mathrm{~N}$ & $\mathrm{~N}$ & 1 & 0 & 3 & 0 & 0 & 0 & 0 & 0 & 2 & 1 & 0 & 0 & 0 & 0 & 0 & 0 & 0 & 0 & 1 & 0 & 0 \\
\hline RS298A & W & 1 & 2 & $\mathrm{~N}$ & $\mathrm{~N}$ & $\mathrm{~N}$ & $\mathrm{~N}$ & 0 & 0 & 4 & 0 & 0 & 0 & 0 & 1 & 2 & 0 & 0 & 0 & 0 & 0 & 0 & 0 & 0 & 0 & 0 & 0 & 0 \\
\hline RS3_498A & W & 1 & 0 & $\mathrm{~N}$ & $\mathrm{~N}$ & $\mathrm{Y}$ & $\mathrm{N}$ & 0 & 0 & 0 & 0 & 0 & 0 & 0 & 0 & 0 & 0 & 0 & 0 & 0 & 0 & 0 & 0 & 0 & 0 & 0 & 0 & 0 \\
\hline RS598A & W & 1 & 2 & $\mathrm{~N}$ & $\mathrm{Y}$ & $\mathrm{Y}$ & $\mathrm{N}$ & 1 & 0 & 1 & 0 & 0 & 0 & 0 & 0 & 0 & 0 & 0 & 0 & 0 & 1 & 0 & 0 & 0 & 0 & 0 & 0 & 0 \\
\hline RS698* & $\mathrm{D}$ & 1 & 1 & $\mathrm{~N}$ & $\mathrm{Y}$ & $\mathrm{Y}$ & $\mathrm{N}$ & 0 & 1 & 0 & 0 & 0 & 0 & 0 & 0 & 0 & 0 & 0 & 0 & 0 & 0 & 0 & 0 & 0 & 0 & 0 & 0 & 0 \\
\hline RS798* & $\mathrm{D}$ & 1 & 0 & $\mathrm{Y}$ & $\mathrm{N}$ & $\mathrm{N}$ & $\mathrm{N}$ & 0 & 0 & 0 & 0 & 0 & 0 & 0 & 0 & 0 & 0 & 0 & 0 & 0 & 0 & 0 & 0 & 0 & 0 & 0 & 0 & 0 \\
\hline RS1198* & $\mathrm{D}$ & 1 & 8 & $\mathrm{~N}$ & $\mathrm{Y}$ & $\mathrm{N}$ & $\mathrm{N}$ & 0 & 8 & 0 & 0 & 0 & 1 & 7 & 0 & 0 & 0 & 0 & 0 & 0 & 0 & 0 & 0 & 0 & 0 & 0 & 0 & 0 \\
\hline RS1398R & $\mathrm{D}$ & 1 & 8 & $\mathrm{~N}$ & $\mathrm{~N}$ & $\mathrm{~N}$ & $\mathrm{~N}$ & 0 & 6 & 0 & 2 & 0 & 2 & 3 & 0 & 0 & 0 & 0 & 0 & 0 & 0 & 0 & 0 & 0 & 0 & 0 & 0 & 0 \\
\hline RS1498R & $\mathrm{D}$ & 1 & 26 & $\mathrm{~N}$ & $\mathrm{~N}$ & $\mathrm{~N}$ & $\mathrm{~N}$ & 0 & 26 & 0 & 0 & 0 & 21 & 0 & 0 & 0 & 0 & 0 & 0 & 0 & 0 & 0 & 0 & 0 & 0 & 0 & 0 & 0 \\
\hline RS1598R & $\mathrm{D}$ & 1 & 5 & $\mathrm{~N}$ & $\mathrm{~N}$ & $\mathrm{~N}$ & $\mathrm{~N}$ & 0 & 4 & 0 & 1 & 0 & 4 & 0 & 0 & 0 & 0 & 0 & 0 & 0 & 0 & 0 & 0 & 0 & 0 & 0 & 0 & 0 \\
\hline RS1698A & W & 1 & 6 & $\mathrm{~N}$ & $\mathrm{~N}$ & $\mathrm{Y}$ & $\mathrm{N}$ & 0 & 0 & 6 & 0 & 0 & 0 & 0 & 0 & 1 & 0 & 0 & 0 & 0 & 0 & 0 & 0 & 0 & 0 & 0 & 0 & 0 \\
\hline RS1798A & W & 1 & 29 & $\mathrm{~N}$ & $\mathrm{Y}$ & Y & $\mathrm{N}$ & 5 & 5 & 18 & 0 & 3 & 2 & 0 & 1 & 6 & 1 & 0 & 1 & 0 & 2 & 0 & 0 & 0 & 0 & 1 & 0 & 0 \\
\hline RS1.196A & W & 2 & 9 & $\mathrm{~N}$ & $\mathrm{~N}$ & $\mathrm{~N}$ & $\mathrm{~N}$ & 8 & 1 & 0 & 0 & 0 & 1 & 0 & 0 & 0 & 0 & 0 & 0 & 0 & 8 & 0 & 0 & 0 & 0 & 0 & 0 & 0 \\
\hline RS296R & $\mathrm{D}$ & 2 & 27 & $\mathrm{~N}$ & $\mathrm{~N}$ & $\mathrm{~N}$ & $\mathrm{~N}$ & 23 & 4 & 0 & 0 & 3 & 1 & 0 & 0 & 0 & 0 & 0 & 0 & 0 & 21 & 0 & 0 & 0 & 0 & 0 & 0 & 0 \\
\hline RS396R & $\mathrm{D}$ & 2 & 36 & $\mathrm{Y}$ & $\mathrm{Y}$ & $\mathrm{N}$ & $\mathrm{Y}$ & 22 & 13 & 2 & 0 & 4 & 6 & 2 & 0 & 0 & 0 & 0 & 0 & 0 & 21 & 0 & 0 & 1 & 0 & 0 & 0 & 0 \\
\hline RS496R & $\mathrm{D}$ & 2 & 29 & $\mathrm{Y}$ & $\mathrm{Y}$ & $\mathrm{N}$ & $\mathrm{N}$ & 12 & 17 & 0 & 0 & 9 & 5 & 3 & 0 & 0 & 0 & 0 & 0 & 0 & 12 & 0 & 0 & 0 & 0 & 0 & 0 & 0 \\
\hline RS596R & $\mathrm{D}$ & 2 & 275 & $\mathrm{Y}$ & $\mathrm{Y}$ & $\mathrm{Y}$ & $\mathrm{Y}$ & 212 & 59 & 2 & 2 & 32 & 4 & 13 & 0 & 0 & 0 & 0 & 0 & 0 & 208 & 1 & 1 & 2 & 0 & 0 & 0 & 0 \\
\hline RS696R & $\mathrm{D}$ & 2 & 6 & $\mathrm{Y}$ & $\mathrm{Y}$ & $\mathrm{N}$ & $\mathrm{N}$ & 2 & 3 & 0 & 0 & 2 & 1 & 0 & 0 & 0 & 0 & 0 & 0 & 0 & 2 & 0 & 0 & 0 & 0 & 0 & 0 & 0 \\
\hline
\end{tabular}

Table 1. Raw data. SL. Sampling labels. F. Facies type: W (wet), D (dry). Q=sequence; NAS=total number of fossil sampled in the layer; $\mathrm{I}=$ ichnofossils; $\mathrm{C}=$ coprolites; $\mathrm{W}=$ "worms"; $\mathrm{O}=$ ostracods; $\mathrm{NF}=$ total number of fish; $\mathrm{NC}=$ total number of crustraceans; $\mathrm{NI}=$ total number of insects; $\mathrm{NB}=$ total number of bivalves; crustaceans: Delclosia shrimps (A); peracarids-espeleogriphaceans (B); austrapotamobius decapods (C); insects: coleopterans (D); belostomatids (E); chrisopids (F); kalligrammatids (G); ephemeropters (H); chresmodids (I). Fish: "leptolepids" (primitive teleostean juveniles) (1); pleuropholidids (2); amiidid (3); Notagogus (4); Gordichthys (5); Lepidotes (6); pycnodontiforms (7); Rubiesichthys (8)

Tabla 1. Datos brutos. SL. Etiquetas del muestreo. F. Tipo de facies W (húmeda), D (árida). Q=secuencia; NAS=número total de fósiles muestreados en la capa; $\mathrm{I}=$ icnofósiles; $\mathrm{C}=$ coprolitos; $\mathrm{W}=$ "gusanos"; $\mathrm{O}=$ ostrácodos; $\mathrm{NF}=$ número total de peces; $\mathrm{NC}=$ número total de crustáceos; $\mathrm{NI}=$ número total de insectos; NB= número total de bivalvos; Crutáceos: gambas Delclosia (A); peracáridos-espeleogrifáceos (B); decápodo Austropotamobius (C); Insectos: coleopteros (D); belostomátidos (E); crisópidos (F); kalligramátidos (G); efemeropteros; chresmódidos (I). Peces: "leptolépidos" (teleósteos primitivos juveniles) (1); pleurofolídidos (2); amiididos (3); Notagogus (4); Gordichthys (5); Lepidotes (6); pycnodontiformes (7); Rubiesichthys (8).

environment, prolonged periods of water stagnation, and the high rate of accumulation of organic debris carried by floods provided the conditions required to maintain anoxic to dysaerobic conditions in the sediments and bottom waters, and prevent reworking of sediments by bioturbators.

\subsection{Fossil taphonomic features}

Fossils from the laminated limestones of Las Hoyas show no evidences for having been transported over long distances, elements are not broken or abraded, indicating all were or produced close to their burial place (parauto- 
Fig. 4.- Stratigraphic correlation, and division into three elemental sequences, of the succession of laminated facies that are included in this study. PS98- Pink Square 98; PS96- Pink Square 96; LmBS- Lowermost Black Square; LBS- Lower Black Square; UPS-Upper Black Square; LS- Lateral sampling that includes the whole stratigraphic span herein considered.

Fig. 4.- Correlación estratigráfica y division en tres secuencias elementales de la sucesión de facies laminadas que se incluyen en este estudio. PS98- Cuadrícula Rosa 98; PS96- Cuadrícula Rosa 96; LmBS- Cuadrícula Negra Basal; LBS- Cuadrícula Negra Inferior; UPS-Cuadrícula Negra Superior; LS- Muestreo lateral continuo que incluye todo el intervalo estratigráfico considerado en este trabajo.

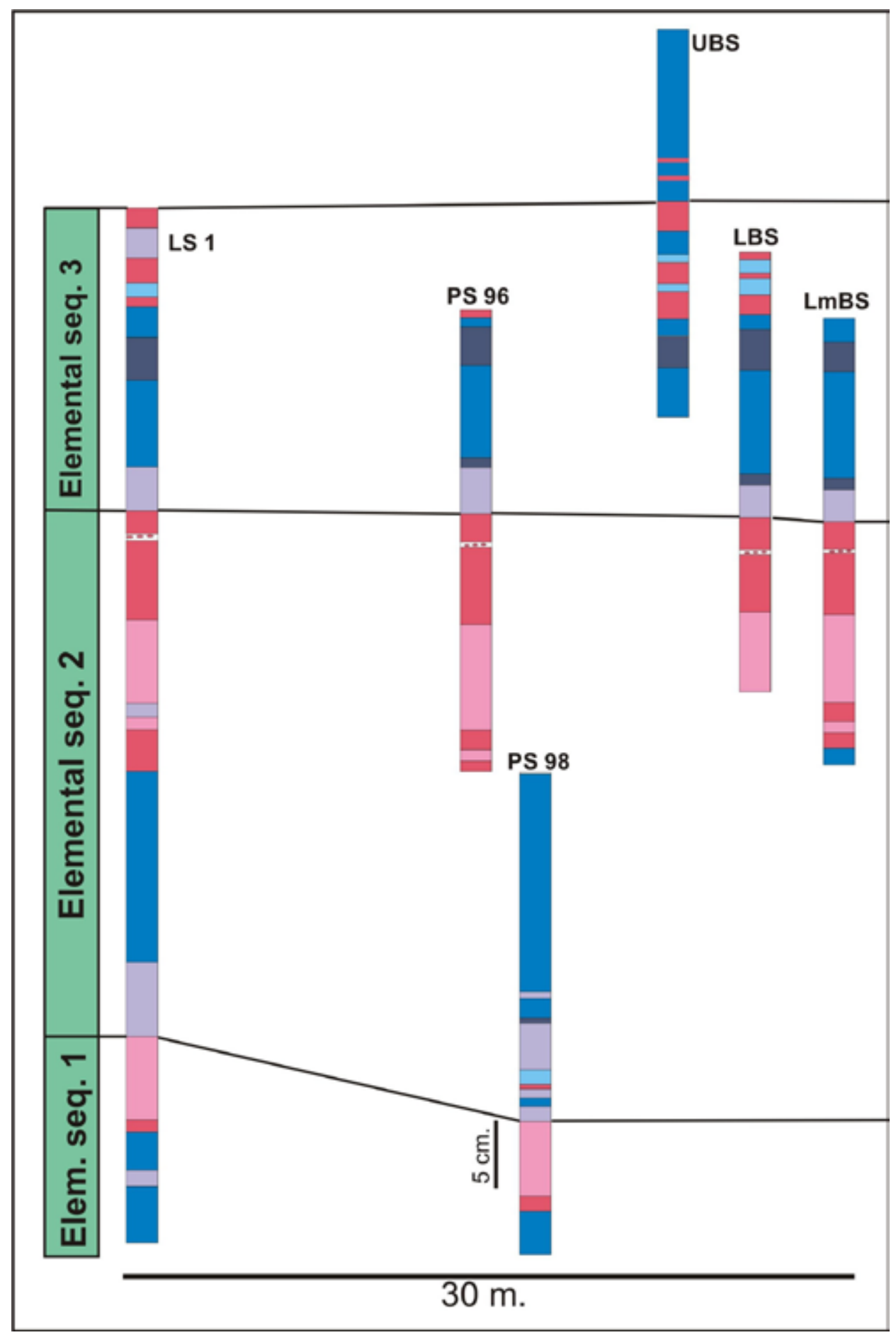

chthonous). $70-80 \%$ of the fossils are fully articulated. The exoskeletons of crustaceans show few disarticulated appendages or antennae (Rabadà, 1993). Insects, which have been more extensively studied, are mostly articulated, especially aquatic species. Aquatic plants (Charophytes, the supposed angiosperm Montsechia and the fernWeichselia) have thalli, stems and fructifications preserved (Martín- Closas and Gomez, 2004). Fish scales preserved in situ and their axial columns and tails remain articulated. Tetrapod skeletons show limited dispersion of body elements with respect to the degree of articulation and overlapping. The autochthonous condition of fossils is consistent with data from molecular taphonomy, suggesting a dominant aliphatic composition of fossil fish scales, plants and decapods, which probably arose from the incorporation of lipids from the original organic sources, indicating preservation by in situ polymerization of labile aliphatic components (Gupta et al., 2008). 
Early ontogenetic stages (juveniles) and adults are commonly present. Numerous moults (exuviae) of young individuals of the heteropterans belostomatid Iberonepa romerali have been noted (Martínez-Delclòs, et al., 1995), and mayflies, flies and coleopteran larvae are quite frequently present (Soriano, 2006; Fregenal-Martínez et al., 2007). Several juvenile salamanders, frogs and crocodilians have been discovered (Ortega et al., 2003). The presence of juvenile and adult dwarf organisms such as fish and belostomatid insects is a common pattern at Las Hoyas, which shows a remarkable bias toward small fossils.

Las Hoyas is a Konservat-Lagerstätte that preserves a broad range of organic components: mineralised muscle, tissue imprints, chitin, cellulose, lignified cellulose, shelly and apatite skeletons (Fig. 5). Preserved eyeballs and peritoneal membranes in fish, and even white banding that may correspond to mineralised replicas of myomeres are quite common. Other examples are the mineralised muscle of the dinosaur Pelecanimimus (Briggs et al., 1997), and the tissue imprints obtained from the albanerpetondid Celtedens. The scaly skin and eyelids, the fingers and toes tightly curled into the centre of the hands and feet, and the intact skin all suggest that this albanerpetondid may have died and dried out (become mummified) before arriving at the burial place (McGowan and Evans, 1995). The crocodile Montsecosuchus has preserved scaly skin and Eoalulavis has limonitized feathers preserved.

Insects and crustaceans are preserved as moulds or mineralised replicas, or as impressions preserving organic matter (Delclòs et al. 2004). Some mecopterans and belostomatids preserve their colour pattern, and their tracheal and gut tracts. Some specimens of the Delclosia carid shrimp preserve digestive organs and eyes. Macroplants are preserved as impressions or as carbonaceous films. Articulated leaves and seeds are abundant, as are stems, twigs, cones and inflorescences. Palynomorphs have also been preserved.

Potential mechanisms that explain the taphonomic features of Las Hoyas are, in descending order of abundance: microbial mats (i.e., bacterial sealing), anoxia and rapid burial by sediments or rapid inclusion in microbial mats.

The contribution of microbial mats (coccoid and filamentous bacteria) has been directly observed in the preservation of tissue imprints in fish eyes (Gupta et al., 2008) and in the dinosaur Pelecanimimus polyodon (Briggs et al., 1997). In this latter, the existence of either a throat pouch or a soft occipital crest demonstrates the importance of microbial mats in preserving soft tissues. The presence of microbial mats might also be confirmed in aquatic insects (Delclòs pers. comm.). In belostomatids (Iberonepa), the inference of microbial mats arises from
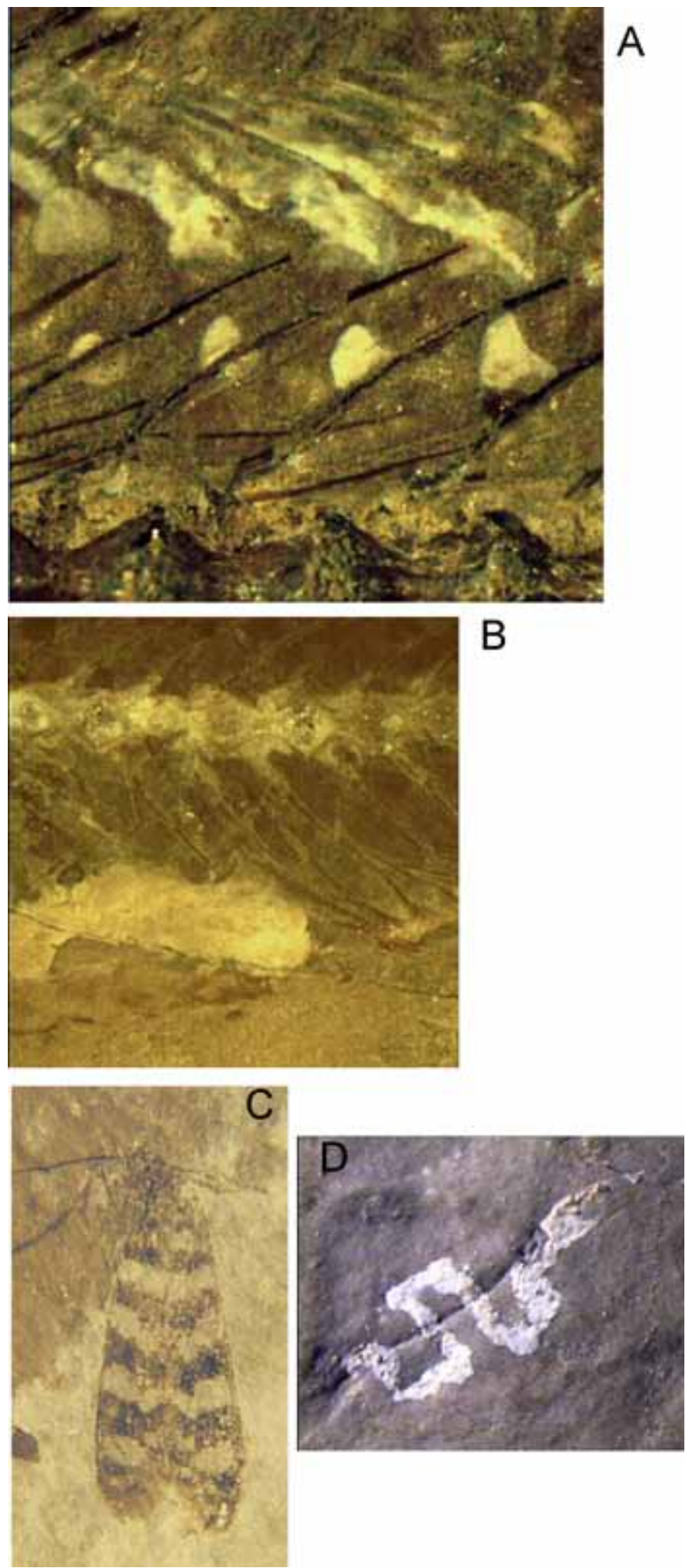

Fig. 5.- Examples of fossil preservation at Las Hoyas. A, white, banded, tissues representing mineralised replicas of fish myomeres.B, faecal mass in fish abdominal cavity.C, colour pattern preserved in Mecoptera wings.D, gut tract preserved in a belostomatid insect.

Fig. 5.- Ejemplos de conservación en los fósiles de Las Hoyas. A. El bandeado blanco corresponde a replicas mineralizadas de miómeros en un pez. B, masa fecal en la cavidad abdominal de un pez. C, patrón de coloración de las alas de un mecóptero. $\mathrm{D}$, tracto digestivo de un insecto belostomátido. 
the analysis of overlapping areas of a body. The mat prevents sediment infilling the cavities and spaces between body parts. The leg and abdomen of Iberonepa may be observed only in the absence of sediment. The confining effects of microbial mats and algae might also promote phosphatization of soft parts, such as gut tracts of fish and aquatic insects and of insect ommatidium.

The near-completeness of articulated appendages in carid decapods, such as the aquatic Delclosia, and bony elements in the terrestrial lizard Hoyalacerta and the aerial aves Concornis, suggest that burial events (or entombing inside microbial mats) were rapid. The comparison of the taphonomic features observed and the results of taphonomic experiments indicate that burial might have taken place in less than 20 days (Briggs, 1995; CambraMoo, 2003; Cambra-Moo and Buscalioni, 2003).

The initial results of a laboratory study using tanks to grow microbial mats under controlled conditions were reported by Iniesto et al., (2009). Fish and insect carcasses are placed upon the mat to measure the time elapsed until embedding by the mat growth, and to observe the decay processes inside the mat. Rapid entombment occurs during this process, and in as little as two weeks individuals become completely covered. They remain fully articulated, retaining delicate anatomical details even after months of decay.

Preservation of body and trace fossils along with laminated facies requires a special set of environmental conditions. As discussed above anoxia is inferred from sedimentological and palaeoichnological analyses to account for such a preservation of fossils and sediments. Ichnological analysis indicates that the Las Hoyas invertebrate ichnofauna (Mermia ichnofacies)displays evidence, such as dominance of superficial structures, the paucity of infaunal traces and a small size that indicate environmental stress due to lack of oxygen, (Buatois et al., 2000) consistent with an environment with short periods of oxygenated bottom waters, but permanently anoxic interstitial waters.

\subsection{Ecological structure}

In terms of biodiversity, metazoans are represented by at least five or six phyla (Porifera, Mollusca, Arthropoda, Chordata and Vermiform animals, such as Nemertina and Annelida) and plants by four (Phycophyta, Bryophyta, Pteridophyta and Spermatophyta). Around 15 families and 17 genera of plants, and 50 families and 80 genera of metazoans have been documented, aquatic organisms being the most abundant. To date, the list of genera has yielded $\mathrm{N}=132$, of which arthropods are by far the most diverse group, representing $45 \%$ of the genera from Las
Hoyas (Fig. 6). The arthropod Classes present are Arachnida, Diplopoda, Crustacea and Hexapoda. The hexapoda is represented by 13 orders (Ephemeroptera, Odonata, Blattodea, Isoptera, Orthoptera, Archaeorthoptera-Chresmodidae, Hemiptera, Coleoptera, Hymenoptera, Trichoptera, Neuroptera, Mecoptera and Diptera) and 40 families (Fregenal-Martínez et al., 2007). The next most abundant groups are the Pteridophyta (15\%) and Ostheichtya (14\%), while the others (Charophyte, Bryophyta, Mollusca, Amphibia, Squamata and Archosauria) make up the remaining percentage of the taxa identified so far (Fregenal-Martínez and Buscalioni, 2009). Thus, the bulk of the taxonomic diversity (67\%) at Las Hoyas is based on arthropods (mainly insects) and plants (Pterydophytes, Spermatophytes, Bryophytes and Algae).

Consistent with sedimentological and palaeonvironmental studies, our working hypothesis is that Las Hoyas was a shallow periphyton-dominated wetland that formed part of a regional-scale depositional system made up of seasonal tropical wetlands. Consequently we would expect the ecological structure to contain: 1) a complex vegetation structure, 2) animal ecology dominated by aquatic taxa, and 3) as wetlands are a mixture of transitional habitats, a hybrid of ecotones with aquatic to terrestrial plants and animals present. This broadly defines this ecosystem as an open system with no clear ecotones that generates a wide variety of microhabitats and environmental mosaicism linked to water availability. This definition is in accordance with the essence of modern wetlands provided by van der Valk (2006).

\section{Complex vegetation structure and insects}

Trophically modern wetland systems are based on the abundance of macrophytes, algae and organic detritus, and on the quality and relative abundance of insects as the second scale of primary production (Batzer et al., 2006). As a wetland Las Hoyas is characterized by the extraordinary dominance of periphytons as revealed by features of its sediment and the exceptional fossil preservation.

The depositional system in which Las Hoyas was located would have been profusely vegetated (Martín-Closas, 2005). The complexity of the vegetation is characterized by the presence of submerged aquatic algae and plants. A very important part of the Las Hoyas fossil assemblage is comprised of aquatic plants. Two types of aquatic macrophytes are the most abundant: charophyte algae (Martín-Closas and Diéguez, 1998), and the early aquatic angiosperm Montsechia (Daviero et al., 2006). Their taphonomic preservation and relative abundance reveals these to be autochthonous. Other aquatic hydrophytes such as the enigmatic Ranunculus ferrerii, or the floating plant Proteaephyllum reniforme are rare at Las Hoyas. 

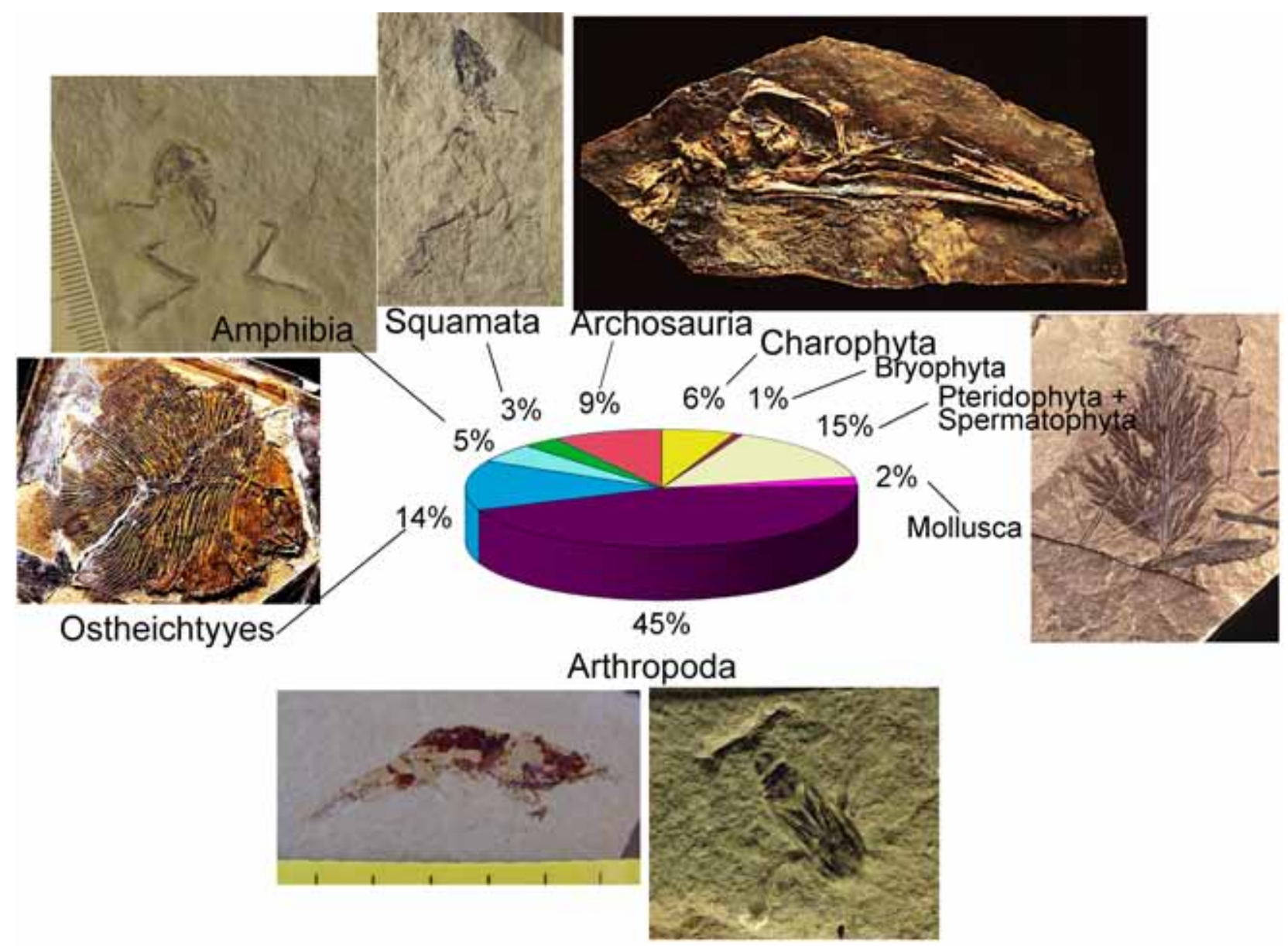

Fig. 6.-Diversity recorded in Las Hoyas. Specimens figured correspond: Ostheichthyes-Turbomesodon MCCMLH-9266; AmphibiaEodiscoglossus; Squamata-MeyasaurusMCCMLH-370; Dinosauria-Pelecanimimus MCCMLH-777; Dicksoniaceae: Onychiopsis; MCCMLH-29503; Heteroptera: Iberonepa MCCMLH-17087, and Caridea: Declosia.MCCMLH-280. Fossils housed at Museo de las Ciencias de Castilla-La Mancha in Cuenca (Spain)

Fig. 6.-Figura compuesta de la diversidad registrada en el yacimiento de Las Hoyas. Los especímenes figurados corresponden a:Ostheichthyes-TurbomesodonMCCMLH-9266; Amphibia-Eodiscoglossus; Squamata-MeyasaurusMCCMLH-370; DinosauriaPelecanimimus; MCCMLH-777; Dicksoniaceae: OnychiopsisMCCMLH-29503; Heteroptera: Iberonepa MCCMLH-17087, and Caridea: Declosia MCCMLH-280. Fósiles pertenecientes a las colección del Museo de las Ciencias de Castilla-La Mancha en Cuenca (España).

There is a high diversity of terrestrial macrophytes. Of the heliophytic plants, conifers are the best represented, with a great diversity of Cheirolepidaceans, Taxodiaceans and Podozamites preserved as leaves, branches and cones. One of the most abundant is the Cheirolepidaceae Frenelopsis. Ferns are dominated by the Mantoniaceae species Weichselia, fossils of which vary in the type of preservation: articulated, fragments of pinnas and pinnulas (occasionally burnt). Bryophtes (Thallites) and herbaceous ferns such as Onychiopsis are fairly abundant, while other herbaceous ferns, such as Cladophlebis and Coniopteris, are frequent to rare in the assemblage. Terrestrial angiosperms are rare, although several leaf types have been recorded in the locality (Barral-Cuesta and Gomez, 2009). Frenelopsis might be adapted to riparian habitats and grew in lacustrine environments (Gómez et al., 2003), while ferns and mosses might form part of moist soil species, or form part of limestone outcrop communities.

High insect diversity and the wide spectrum of ecomorphotypes represented (zooplanktivorous, herbivorous, carnivorous, scavengers, xylophagous, saprophagous) reflect the environmental mosaicism of wetland systems. Abundance is biased towards aquatic insects that exhibit a wide range of ontogenetic stages (from larvae, pupae and exuviae to adults). Conversely, terrestrial forms are less abundant but more diverse, and in terms of preservation insects are represented by complete specimens and by isolated body parts mostly wings. This is demonstrated by coleopterans (Soriano, 2006) where abundance is concentrated in the aquatic family Coptoclavidae, but diversity increases in the terrestrial forms Cupedidae and 
Scarabaeidae. Semi-aquatic insects and other groups living around vegetation and water bodies include grasshoppers, crickets, dragonflies, or neuropterans, caddis fly larvae and some larvae of the beetle Coptoclavidae (for details see Ponomarenko \& Martínez-Delclòs 2000, Soriano et al. 2007). Parandrexidae beetles, Cupedid reticulated beetles, weevils and several forms of cockroaches and termites are associated with terrestrial environments, above all with wood and fungi (Martínez-Delclòs 1991, 1993, Zherikhin and Gratshev 2003, Soriano et al. 2006, Soriano and Delclòs 2006). Arachnids, particularly orbweaver spiders, also form part of the terrestrial cluster (Selden and Penny, 2003).

\section{Animal ecology}

The lentic freshwater ecosystem of Las Hoyas contains one of the most significant records described for the Early Cretaceous (Sanz et al., 2001). The organization of animal ecology at Las Hoyas has been analysed using the ecological categories defined for extant wetlands. The aim is to test to the extent to which an ancient ecosystem might correspond in composition and relative abundance those characteristics of modern systems. These categories are founded on the life cycles and the dependence of animals on wetland hydrology. The species can be grouped in the following categories: (1) obligate aquatic: found either in the water column or in flooded soils, (2) amphibious: species considered to spend at least part of their life cycle in wetlands and the remainder in some terrestrial environment, (3) facultative: species that may be found in wetlands and terrestrial environments, and (4) incidental: species occasionally found in wetlands.

Results from Buscalioni et al. (2008) reveal that Las Hoyas was dominated by obligate aquatic taxa $(64 \%$; in this previous study arthropods and macrophytes were excluded, although crustaceans, and some insects groups are also obligate aquatic), $24 \%$ of amphibious taxa, but fewer facultative to incidental forms $(12 \%)$.

Of the obligate aquatic organisms, there are thousands of fish specimens. They are focal wetland animals because they are keystone species in terms of their ecological role, the productivity of wetlands being mainly based on fish biomass (Batzer et al., 2006). As a general condition, most dominant fishes in modern wetlands are small-sized species and small individuals. Protected wetland areas, as seems to be the case for Las Hoyas, are places selected by fished for protection from predators and as nesting areas. This would explain the bias towards juvenile individuals at this locality. Las Hoyas is not special in this sense, since the most abundant individuals are small juveniles of Notagogus (Wenz and Poyato-Ariza, 1994), anda basal teleostean fish, formerly related to "leptolepids" (PoyatoAriza, 1997). Other teleostean species, such as the genera of the family Chanidae, Gordichthys and Rubiesichthys, are frequent, and are also small species. Species with a medium-to-large body size are less abundant. These include pycnodontiform fish like Turbomesodon, the coelacanth "Holophagus" (one of the largest), Lepidotes, and several amiiform species (Vidalamia, Caturus and Amiopsis) (Poyato-Ariza and Wenz, 2004).

The most abundant aquatic insect is the belostomatid Iberonepa, which has adaptations for active swimming, with its appendicular segments transformed into paddles. Less abundant although still frequent are insects that exhibit morphological aquatic adaptations for locomotion or feeding strategies, such as coptoclavid coleopterans, chresmodids, dipterans larvae, odonates, anisopterans (see Fregenal-Martínez et al., 2007 for a summary). Most aquatic insects depend on plant shelter. The presence of mayflies (Ephemeroptera), preserved as nymphs and adults at Las Hoyas, might indicate oxygenated waters, since oxygen stress prevents many aquatic animals groups from occupying poorly oxygenated wetlands (Mendelssohn and Batzer, 2006). This condition is supported by the absence of midges (Chironomids), which are the aquatic insects best adapted to low oxygen levels in modern wetlands (van der Valk, 2006).

Decapods are the most abundant invertebrates in Las Hoyas. Their trophic regimes range from omnivorous to scavenging (for the astacid decapod Austropotamobius, Garassino, 1996) to feeding on periphyton (as may be the case for the shrimp Declosia, since it occurs in modern relatives; Burns and Walker, 2000). The presence of peracarids, the minute spelaeogriphaceans, with a poor and patchy fossil record, and today live in fresh groundwater limestone caves should also be noted (Jaume, 2008). Other crustaceans, such as ostracods, have also been recovered at Las Hoyas, associated with mass mortality or invasion, as well as other invertebrates made up of a plethora of rather small- to medium-sized worm-like organisms whose taxonomy is difficult to establish because no fossil record is described for them.

Unionid bivalves and conchostraceans are also present and reveal that Las Hoyas water would have been alkaline, since the recent equivalents of these organisms typically live in alkaline waters, ranging in $\mathrm{pH}$ from 6.6 to 9.5 (for unionids see Good, 2004). Water alkalinity was deduced from independent criteria using sedimentological and geochemical sources (Poyato-Ariza et al., 1998). The amphibious category gathers those species that are considered to spend at least part of their life cycle in wetlands and the remainder in a terrestrial environment; 
albanerpetontids, anurans, caudates as well as chelonians and crocodylomorphs form part of this category. Albanerpetontids and crocodylomorphs are by far the most dominant groups. Turtles are rare (a new centrocrytodyrian turtle is represented by three juvenile specimens that do not exceed $20 \mathrm{~cm}$ in body length). Within this category some taxa might be more terrestrial and less waterdependent. For instance, the albanerpetontid Celtedens had terrestrial adaptations. In contrast, the salamander 'Hylaeobatrachus' retained its external gills and is therefore definitely fully aquatic (Evans and Milner, 1996). In the same sense, two groups of crocodylomorphs are included in this biota, one with terrestrial adaptations (a gobiosuchid, Buscalioni et al., 1996, Ortega, 2004) and the other possessing aquatic life habits (advanced neosuchians). It is worth noting that most of the recovered specimens in the amphibious category are juveniles and/ or small-sized species.

Facultative species are diverse but rare. Lizards and dinosaurs were facultative and incidental terrestrial components of this biota, respectively. The terrestrial habits of the Las Hoyas lizard biota include the runner Meyasaurus (the most abundant species), the climber Scandensia and the burrower Hoyalacerta (Evans and Barbadillo, 1998). Non-avian dinosaur body fossils are extremely rare, and the group comprises medium- to small-sized individuals, among including the ornithomimosaur Pelecanimimus (Pérez-Moreno et al., 1994). Dinosaur ichnofossils are fairly common, although their presence seems to be linked to particular palaeoenvironmental settings (see below). Pterosaurs have also been categorized as facultative to incidental organisms. Fossils belonging to this group occur as isolated teeth and a partially articulated skull (Vullo et al., 2009).

Birds,the other focal wetland animals, can be considered to fall within a wide range of categories from amphibious to incidentals. Las Hoyas has yielded a high diversity of Enantiornithes aves. Species recorded (Iberomesornis romerali, Eoalulavis hoyasi and Concornis lacustris) have interpreted as being perching enantiornithines of reduced size with enhanced flight capabilities, allowing low speed flight and good manoeuverability (Sanz et al., 2000, 2002; Ortega et al., 1999). The life history of enantiornithes may be more strongly linked to wetland ecosystems than was previously thought. For instance, Eoalulavis (Sanz et al., 1996) adopted limicol habits, feeding on worms and crustaceans at the shores of water bodies, and the morphology of these birds (e.g., long legs with long toes) might also represent limb adaptations as in modern wading birds.

\subsection{Concluding remarks}

In summary, the interplay among the sedimentary analyses, taphonomy and ecological structure confirms the palaeonvironmental hypothesis that stresses four important features of the fossil record at Las Hoyas: 1) Compared with modern wetland ecosystems in terms of recorded phyla and diversity, Las Hoyas is highly representative, i.e., it has a high fidelity of composition: its fossil record "captures the original biological information faithfully, accurately, truthfully"(sensu Behrensmeyer et al., 2000). 2) When relative abundance is taken into account, macrophytes, arthropods (crustacean and aquatic insects), and small teleostean fish are the dominant taxa, as would be expected from the freshwater environmental setting. A diverse assemblage of animals including aquatic insects, ostracods, crayfish, and juvenile and small adult fishes depended on plant cover for their development and shelter. In fact, with respect to the obligate aquatics, the epibenthos and epiphyton of the Las Hoyas ecosystem is the habitat containing the greatest relative abundance. 3) The strong influence biofilms in the association are abundant and play a major role in fossil preservation. 4) Some groups in the fossil association corroborate or improve our knowledge of particular abiotic conditions of the ecosystem.

\section{Assembling the taphonomic and stratigraphical records: assessing biases and interpreting dynamics. "Dynamic" approach}

The palaeoecological reconstruction of Las Hoyas ecosystem outlined above is part of an integrated research effort. Many of the details that can be identified regarding particular morphological adaptations reflect the unique conditions of preservation of the Konservat-Lagerstätten. From this perspective, it may be said that Las Hoyas as a Konservat-Lagerstätte is a "canon" of preservation with maximum information, i.e., a minimally biased association in which information can be directly read because of the very high fidelity of its composition (Behrensmeyer et al., 2000). If this is true Las Hoyas might be used $a$ priori as a reference or model to reconstruct the palaeobiology and palaeoecology of other, similar, Lower Cretaceous freshwater deposits.

Reconstructions made by considering the complete fossil content are essentially a "frozen picture" of the landscape with its flora and fauna. This "static" approach is compromised by the intuitive observation that ecological dynamics are never preserved as such. In effect, this method cannot avoid flattening the ecological and taphonomic 
processes to a single entity, amalgamating data or processes that came from different ecological dynamics in the palaeoecological reconstruction. As no other sources of bias are taken into account, the diversity recorded might be distorted and result in an incongruent assemblage.

To address this problem, we employ a dynamic approach to palaeoecological reconstruction, and explore whether Las Hoyas in particular, and Konservat-Lagerstätten in general, behave assingle entities. In other words, we attempt to establish whether Las Hoyas represents a unique ecosystem that can be regarded as a taphonomic unit. Therefore, we will place the palaeobiology and taphonomy of Las Hoyas within its actual spatio-temporal framework, and address the following key questions:

What is the specific bias of Konservat-Lagerstattën deposits? How can we prospect the resolution (temporal) and fidelity (spatial) of the "canon" itself? Does a unique taphonomic structure explain the abundance?

Is the total recorded diversity better explained in terms of time resolution? By this we mean: does Las Hoyas provide such temporal stratigraphic resolution that would reveal successive ecosystems? Alternatively, is the more general explanation in terms of spatial fidelity the better one? In other words, does Las Hoyas provide evidence of isochronous laterally coexisting ecosystems?

How are sedimentary tempo and, biological and/or ecological tempo related?

\subsection{The stratigraphic record of Las Hoyas}

Temporal distribution of palaeobiological information is strongly dependent on the structure of the stratigraphic record. An adequate palaeobiological interpretation requires a detailed understanding of the stratigraphical architecture in terms of time and sedimentary environments. However, this relationship has not always been well understood or given sufficient emphasis. Different approaches to assess either palaeobiological or stratigraphic completeness have been used (Kidwell, 1991, 1993). Holland (1997, 2000) showed how introducing sequence stratigraphy in macroevolutionary analyses results in a predictive model for bias in the large-scale structure of the fossil record.

Sedimentology is an essential tool for establishing the environmental context, the landscape of reconstructed fossil ecosystems, and for comparing data with the biostratinomic hypothesis. For these reasons, it is currently considered extremely relevant in palaeoecology (Behrensmeyer et al., 2000). Nevertheless, on reviewing the palaeoecological literature it becomes obvious that the potential when analyses of the stratigraphical architec- ture, sedimentology and the fossil record are combined to provide palaeoecological hypotheses, has been underestimated. The stratigraphical record of each sedimentary basin has a specific set of features or patterns that, as in biostratigraphy, may contribute to creating or enhancing bias and artefacts at different scales. These may be relevant to our understanding of the dynamics of palaeoecological communities.

The record from Las Hoyas, as with other lacustrine localities, is an exceptional palaeoenviromental archive with high temporal resolution (Cohen, 2003). The continuity and temporal resolution of the lacustrine deposits of Las Hoyas (low time averaging) and its unique palaeobiological and taphonomic features qualifies Las Hoyas as a natural laboratory where reconstruction of ancient Mesozoic continental ecosystems can be carried out within a dynamic context (Buscalioni and FregenalMartínez, 2003).

Las Hoyas is made up of two facies associations that correspond to sedimentation during wet and dry periods (see section 4.1 and Fig. 3).

The stratigraphic arrangement of facies follows a cyclic vertical pattern (Figs. 3 and 4), primarily controlled by the seasonal alternation of wet and dry environmental conditions. This basic alternation is arranged in elemental sequences made up of a variable number of single laminites, numbering up to several hundred (Figs. 3 and 4). These sequences are 20 - to 50 -cm-thick, laterally persistent sequences, with sharp and well defined lower and upper boundaries. The lower part is dominated by facies developed during a wet period, gradually moving upwards to facies representing drier periods. Thus, each elemental sequenceisconsidered equivalent in terms of temporal meaning and tendency to other well-known cycles, such as metric to decimetric cycles made up of marls, charophyte limestones and palustrine limestones representing infilling and reduction of the depth of small lakes and ponds.

Wet and dry periods of the elemental sequences reflect cyclicity imposed over the annual seasonal cycles. Such long term cyclicity might have been controlled by a combination of climate and other allocylical processes. Determining the time represented by each elemental cycle is not easy, but given their nature and origin, the order of $10^{3}$ years might be a reasonable estimate (Buscalioni and Fregenal-Martínez, 2003).

\subsection{Environmental dynamics: facies bias}

Due to the specific nature of the sedimentation processes involved in forming Las Hoyas (continuity and 


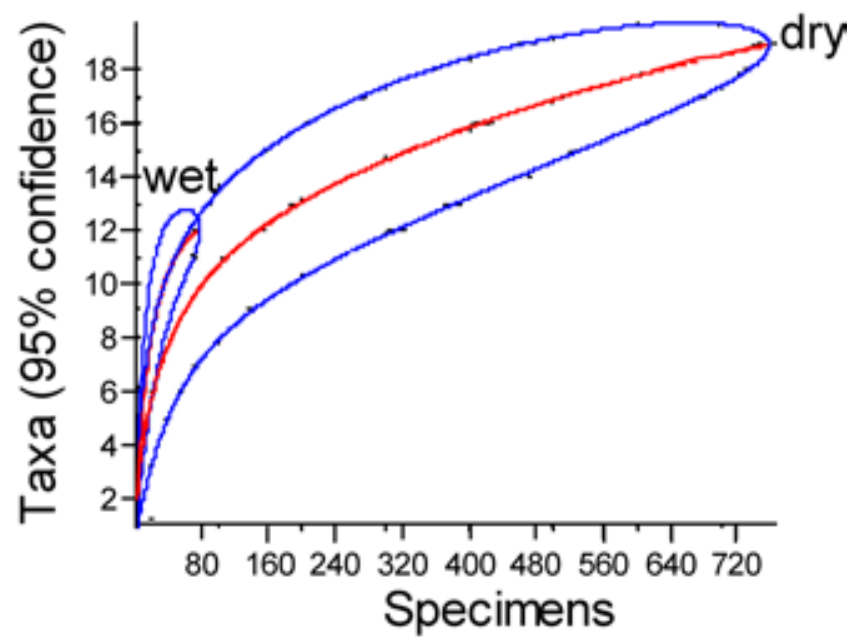

Fig. 7.- Rarefaction curves with $95 \%$ confidence intervals ("banana plot") for the wet and dry associations calculated using PASTC program (Hammer and Harper, 2008).

Fig. 7.- Curvas de rarefacción con $95 \%$ de intervalo de confianza ("contorno de banana") para las asociaciones húmedas y secas, calculadas usando el programa PAST ( ) (Hammer and Harper, 2008).

high temporal resolution) each lamina is considered to represent a snapshot, with fairly instant (census) time averaging. Assuming this, we can infer associations (recognised by the presence of the same species in several assemblages) made of the piles of successive assemblages. Many associations at Las Hoyas are characterised by: i) instantaneous events such as daily activity (e.g., digestion, mass mortality), or ii) high proportion of demic organisms (e.g., with serial of ontogenetic stages) and autochthonous fossils accreted in short-scale events of fossil accumulation, all of which are of similar size and preservation type.

The relationships between the sedimentation during wet and dry periods and fossil associations in each facies have been compared independently of the elemental sedimentary cycle from which they were retrieved. The objective is to reveal the changes that each environmental signal produces in the pattern of association.

There were 764 fossil specimens in the dry association, and 76 in the wet association (Table 2). When coprolites and "worms" were considered the total number of sampled fossils was 829 and 93, respectively. This disparity in the results can be interpreted by using rarefaction curves (Fig. 7) that compare taxon counts in samples of different size. The curve shows that wet and dry facies have different rarefaction curves. Wet associations are richer despite their low abundance, while dry associations are strikingly abundant although homogeneous. Wet and dry episodes differ not only with respect to the total number of fossils but also in their richness and taxon content. These peculiarities are reflected in the resulting richness and diversity indices (Table 2).

Characterisation of the association in dry facies follows its own model, in which time-averaging seems to be of a lesser order of magnitude than for wet periods. This rich association could be the by-product of dense microbial mats, probably acting under a shallow water layer. Fossils trapped by the microbial mat show that a reliable sequence of ecological events occurred in the wetland during periods of environmental stress: bioturbation (invertebrate traces), ostracod invasion, periodic storms, coprolite or "worm-larva" accumulations, and mass mortality of small juvenile basal teleosteans and/or crayfish. Accumulation by mass mortality and tetrapod traces contributes hundreds of elements.

The analysis of the fossil associations shows that demicity and autochthony are the major features of the dry associations. This can also be applied to shallow water inhabitants of the dry episodes formed by small juvenile teleostean fishes, carid shrimps (Delclosia), peracarid spelaeogriphaceans and astacid decapods (Austropotamobius) together with the presence of the aquatic angiosperm Montsechia. Necktonic fish, epibenthonic shrimps, and peracarids are dominant elements (up to $65 \%$ and $25 \%$ of the total amount of body fossils in dry facies, respectively).

The fish association is characterised mainly by small animals (mean body length, 15 to $20 \mathrm{~mm}$ ). In dry associations, juvenile basal teleosteans ("leptolepid-like") are dominant elements whose ecomorphotypes have been associated with plankton filter organisms (Poyato-Ariza, 2005). Furthermore, the fish assemblage (i.e., "leptolepidlike", Notagogus, Pleuropholis, Rubieschthys and Gordichthys) features low fusiform bodies, whose skeletons have led these species to being functionally interpreted as active swimmers (Rubieschthys), or dwellers of superficial waters (basal teleosteans and Gordichthys) (see Poyato-Ariza, 2005, for fish ecomorphology). One of the striking characteristics of the association is the low proportion of insects, as a whole (except for aquatic heteropterans), during long drier intervals. Finally, occasional exclusion between the aquatic plants, Charophytes and Montsechia, apparently occurs.

Wet facies are proportionally rich, because almost all specimens belong to different taxa (genera or species). Plant debris is the most commonly found type of remain. Fieldwork observations record "bad-preservation" for these fossils (in the Las Hoyas preservational context), and denote the presence of isolated elements such as scales, or non-articulated fish bones. Wet facies show dif- 
1)

\begin{tabular}{|c|c|c|c|c|c|c|c|c|c|c|c|c|c|c|c|c|c|c|c|c|c|c|c|c|c|}
\hline WET & 0 & 0 & 5 & 4 & 25 & 6 & 0 & 44 & 3 & 3 & 0 & 4 & 16 & 4 & 2 & 1 & 0 & 12 & 0 & 0 & 0 & 0 & 8 & 1 & 0 \\
\hline DRY & 8 & 4 & 15 & 6 & 473 & 222 & 7 & 62 & 124 & 45 & 30 & 11 & 29 & 2 & 1 & 2 & 3 & 453 & 1 & 1 & 7 & 1 & 7 & 0 & 1 \\
\hline VAR & $\mathbf{I}^{*}$ & $\mathbf{O}^{*}$ & $\mathbf{C}^{*}$ & $\mathbf{W}^{*}$ & $\mathbf{N F}$ & $\mathbf{N C}$ & $\mathbf{N B}$ & $\mathbf{N I}$ & $\mathbf{A}$ & $\mathbf{B}$ & $\mathbf{C}$ & $\mathbf{D}$ & $\mathbf{E}$ & $\mathbf{F}$ & $\mathbf{G}$ & $\mathbf{H}$ & $\mathbf{I}$ & $\mathbf{1}$ & $\mathbf{2}$ & $\mathbf{3}$ & $\mathbf{4}$ & $\mathbf{5}$ & $\mathbf{6}$ & $\mathbf{7}$ & $\mathbf{8}$ \\
\hline
\end{tabular}

2)

\begin{tabular}{|c|c|c|c|c|c|c|c|c|c|c|c|c|c|c|c|c|c|c|c|c|c|c|}
\hline 3 & 3 & 0 & 4 & 16 & 4 & 2 & 1 & 0 & 12 & 0 & 0 & 0 & 0 & 8 & 1 & 0 & 4 & 0 & 18 & 0 & 76 & WET \\
\hline 124 & 45 & 30 & 11 & 29 & 2 & 1 & 2 & 3 & 453 & 1 & 1 & 7 & 1 & 7 & 0 & 1 & 2 & 23 & 14 & 7 & 764 & DRY \\
\hline $\mathbf{A}$ & $\mathbf{B}$ & $\mathbf{C}$ & $\mathbf{D}$ & $\mathbf{E}$ & $\mathbf{F}$ & $\mathbf{G}$ & $\mathbf{H}$ & $\mathbf{I}$ & $\mathbf{1}$ & $\mathbf{2}$ & $\mathbf{3}$ & $\mathbf{4}$ & $\mathbf{5}$ & $\mathbf{6}$ & $\mathbf{7}$ & $\mathbf{8}$ & FI & CI & II & BI & NASS & VAR \\
\hline
\end{tabular}

3)

\begin{tabular}{lcccc}
0 & wet & dry & Boot $\mathrm{p}(\mathrm{eq})$ & Perm $\mathrm{p}(\mathrm{eq})$ \\
\hline Taxa S & 12 & 19 & 0.615 & 0.888 \\
Individuals & 76 & 757 & 0 & 0 \\
Dominance & 0.1489 & 0.3932 & 0 & 0.001 \\
Shannon H & 2.127 & 1.465 & 0 & 0.001 \\
Evenness $\mathrm{e}^{\wedge} \mathrm{H} / \mathrm{S}$ & 0.6994 & 0.2278 & 0 & 0 \\
Simpson index & 0.8511 & 0.6068 & 0 & 0.001 \\
Menhinick & 1.376 & 0.6906 & 0.256 & 0.139 \\
Margalef & 2.54 & 2.715 & 0.76 & 0.903 \\
Equitability J & 0.8561 & 0.4976 & 0 & 0 \\
Fisher alpha & 4.008 & 3.538 & 0.464 & 0.565 \\
Berger-Parker & 0.2368 & 0.5984 & 0 & 0 \\
\hline
\end{tabular}

Table 2.- 1. Total number of fossils in wet and dry associations. VAR= variables; NAS=total number of fossil sampled in the layer; I=ichnofossils; $\mathrm{C}=$ Coprolites; $\mathrm{W}=$ "worms; $\mathrm{O}=$ ostracods; * asterisk denotes number of observations, and it does not represent the total number of individuals recorded. $\mathrm{NF}=$ total number of fish; $\mathrm{NC}=$ total number of crustraceans; $\mathrm{NI}=$ total number of insects; $\mathrm{NB}=$ total number of bivalves; $\mathrm{Crustaceans:}$ Delclosia shrimps (A); peracarids-spelaeogriphaceans (B); Austropotamobius decapods (C); Insects: coleopterans (D); belostomatids (E); Chrisopids (F); Kalligrammatids (G); Ephemoropterans (H); Chremodids (I). Fish: "leptolepids" (primitive teleostean juveniles) (1); pleuropholidids (2); amiidid (3); Notagogus (4); Gordichthys (5); Lepidotes (6); pycnodontiforms (7); Rubiesichthys (8). 2. Data used in the estimation of rarefaction curves. Data are represented in figure $6 . \mathrm{FI}=$ undetermined fish; $\mathrm{CI}=$ undetermined crustaceans, $\mathrm{II}=$ undetermined insects; $\mathrm{BI}=$ undetermined bivalves; NASS=total number of collected fossils. 3. Richness and diversity indices for the two samples (wet and dry), with probabilities of equality $\mathrm{p}<0.05$. To evaluate species richness in the two samples, note that Menhinick richness index is higher is the wet association. This index attempts at compensating for sample size (Hammer and Harper, 2008). Other indices such as Dominance, Evenness and Berger-Parker, attempt to incorporate relative abundance. Note here that the higher abundance and homogeneous composition of the dry association result in greater values of Dominance and Berger-Parker indices. Results from PASTC program (Hammer and Harper, 2008).

Tabla 2.- Arriba: Número toral de fósiles en las asociaciones secas y áridas. VAR= variables; NAS=número total de fósiles muestreados en la capa; $\mathrm{I}=$ icnofósiles; $\mathrm{C}=$ coprolitos; $\mathrm{W}=$ "gusanos"; $\mathrm{O}=$ ostrácodos;*el asterisco señala el número de observaciones, pero no indica el número total de individuos registrados. $\mathrm{NF}=$ número tal de peces; $\mathrm{NC}=$ número total de crustáceos; $\mathrm{NI}=$ número total de insectos; $\mathrm{NB}=$ número total de bivalvos; Crustáceos: gamba Delclosia (A); peracáridos-espeleogrifáceos (B); decápodo Austropotamobius (C); Insectos: coleopteros (D); belostomátidos (E); Crisópidos (F); Kalligrámmatidos (G); Efemeropteros (H); Cresmódidos (I). Peces: "leptolépidos" (teleósteos juveniles primitivos) (1); pleurofolídidos (2); amiididos (3); Notagogus (4); Gordichthys (5); Lepidotes (6); pycnodontiformes (7); Rubiesichthys (8). Abajo: Datos utilizados en la estimación de las curvas de rarefacción. Los datos han sido representados en la figura 6 . FI= peces sin identificar; CI= crustáceos indeterminados; $\mathrm{II}=$ insectos indeterminados; $\mathrm{BI}=$ bivalvos indeterminados; NASS= número total de fósiles recogidos. 3. Índices de riqueza y de diversidad para las dos muestras (húmeda y árida), con probabilidades de semejanza $p<0.05$. Para evaluar la riqueza de especies en las dos muestras, nótese que el índice de riqueza Menhinick es más alto en la asociación húmeda. Este índice intenta compensar el tamaño de la muestra (Hammer and Harper, 2008). Otros índices como el de Dominancia, Rareza y Berger-Parker incorpora la abundancia relativa. Nótese la alta abundancia y la composición homogénea de las asociación árida que dan valores mayores en los índices de Dominancia y de Berger-Parker. Resultados de PASTC (Hammer and Harper, 2008).

ferent fossil preservation compared with dry facies. Although the wet sample is limited, insects, Lepidotes and Pycnodontiform fish dominate wet assemblages. Fish have distinct bulky and globular body shapes characteristic of oscillatory locomotion, with average sizes of up to $55 \mathrm{~mm}$ at Las Hoyas (the largest individuals are about $500 \mathrm{~mm}$ ). Insect distribution is bounded by wet episodes, i.e., they were collected in the wettest facies and in wet facies bounded by drier ones. Insects collected are either aquatic (Iberonepa, Torcanepa, Diptera, Ephemeroptera and Odonata larvae) or terrestrial (Blattodea, Chresmodidae, Chrysopidae and Kalligrammatidae). The abundance of aquatic forms exceeds the terrestrial ones. Moulds of Iberonepa have also been retrieved, implying a demic production of these body fossils. The insect diversity (more than six species) in these facies is extraordinary. The increase in insect diversity in wetter facies is not unexpected since, as a general pattern, their life cycles are related to flooding or wetter periods in modern wetlands (Mendelssohn and Batzer, 2006). 


\begin{tabular}{|c|c|c|c|c|c|c|c|c|c|c|c|c|c|c|c|c|c|c|c|c|c|c|c|}
\hline SQ & $\mathbf{F}$ & NASS & NF & $\mathrm{NC}$ & $\mathbf{A}$ & B & C & 1 & 2 & 3 & 4 & 5 & 6 & 7 & 8 & NB & NI & D & $\mathbf{E}$ & $\mathbf{F}$ & G & $\mathbf{H}$ & I \\
\hline NI02NS5_9 & $\mathrm{D}$ & 10.48 & 3.16 & 7.07 & 6.92 & 0 & 0 & 1.41 & 0 & 0 & 1 & 0 & 2.64 & 0 & 0 & 1.41 & 6.55 & 2.44 & 5.29 & 1.41 & 1 & 1.41 & 1.41 \\
\hline NI2NI9 & $\mathrm{W}$ & 3.1 & 2 & 0 & 0 & 0 & 0 & 0 & 0 & 0 & 0 & 0 & 2 & 0 & 0 & 0 & 2.44 & 1 & 1 & 1.41 & 1 & 0 & 0 \\
\hline NI10NI15 & $\mathrm{D}$ & 10.58 & 8.42 & 3.87 & 3.74 & 0 & 1 & 8.30 & 0 & 0 & 1 & 1 & 0 & 0 & 0 & 0 & 3 & 1.41 & 1 & 0 & 0 & 0 & 0 \\
\hline NS1NS4 & $\mathrm{W}$ & 1.73 & 1 & 0 & 0 & 0 & 0 & 0 & 0 & 0 & 0 & 0 & 0 & 0 & 0 & 0 & 1.41 & 0 & 1.41 & 0 & 0 & 0 & 0 \\
\hline NS5NS9 & $\mathrm{D}$ & 7.14 & 2.23 & 2 & 1.73 & 0 & 0 & 1.41 & 0 & 0 & 1 & 0 & 1.41 & 0 & 0 & 1 & 5.83 & 2 & 4.58 & 1.41 & 1 & 1.41 & 1.41 \\
\hline NS10NS14 & $\mathrm{W}$ & 2 & 1 & 0 & 0 & 0 & 0 & 0 & 0 & 0 & 0 & 0 & 0 & 0 & 0 & 0 & 1.73 & 1 & 1 & 0 & 1 & 0 & 0 \\
\hline NSC1NSC5 & $\mathrm{W}$ & 1.73 & 1.41 & 0 & 0 & 0 & 0 & 1 & 0 & 0 & 0 & 0 & 1 & 0 & 0 & 0 & 1 & 0 & 1 & 0 & 0 & 0 & 0 \\
\hline NSC6NSC10 & $\mathrm{D}$ & 13.90 & 11 & 4 & 3.46 & 0 & 1 & 10.86 & 0 & 0 & 1.41 & 0 & 0 & 0 & 1 & 0 & 2.44 & 1.73 & 0 & 0 & 0 & 0 & 1 \\
\hline NSC11 & W & 1.41 & 1.41 & 0 & 0 & 0 & 0 & 0 & 0 & 0 & 0 & 0 & 1 & 1 & 0 & 0 & 0 & 0 & 0 & 0 & 0 & 0 & 0 \\
\hline R9801R985 & W & 3.16 & 1.41 & 0 & 0 & 0 & 0 & 1 & 0 & 0 & 0 & 0 & 1 & 0 & 0 & 0 & 2.82 & 1 & 2 & 1 & 0 & 0 & 0 \\
\hline R986R9815 & $\mathrm{D}$ & 6.92 & 0 & 6.70 & 0 & 5.29 & 3.16 & 0 & 0 & 0 & 0 & 0 & 0 & 0 & 0 & 1.73 & 0 & 0 & 0 & 0 & 0 & 0 & 0 \\
\hline R9816R9817 & W & 5.91 & 2.23 & 2.23 & 1.73 & 1.41 & 0 & 1.41 & 0 & 0 & 0 & 0 & 1 & 0 & 0 & 0 & 4.90 & 1 & 2.64 & 1 & 0 & 1 & 0 \\
\hline R961.1 & W & 3 & 2.82 & 1 & 0 & 1 & 0 & 2.82 & 0 & 0 & 0 & 0 & 0 & 0 & 0 & 0 & 0 & 0 & 0 & 0 & 0 & 0 & 0 \\
\hline R962R966 & $\mathrm{D}$ & 19.31 & 16.46 & 9.80 & 7.07 & 4.12 & 4.24 & 16.24 & 1 & 1 & 1.73 & 0 & 0 & 0 & 0 & 1.41 & 2 & 0 & 0 & 0 & 0 & 0 & 0 \\
\hline
\end{tabular}

Table 3.- Root transformed data for Cluster Analysis. Leyend as in Table 1. See figure 8 for the resulting Cluster.

Tabla 3.- Datos transformados para el análisis de aglomeración. Leyenda como en la Tabla 1.

Neuston may represent $44 \%$ of the total sample in some cases, while nektonic organisms account for only $13 \%$. During wet periods the positive water balance would promote more lacustrine conditions and a deeper water layer. The presence of big fishes in the association strengthens this assessment. Medium- to large-bodied fish are thought to be bottom dwellers (Pycnodontiforms), and show an efficient hydrodynamic design (Lepidotes) (Poyato-Ariza, 2005). Transport of materials, including potentially carcasses, is common in wet facies;some laminae have a tractive origin. Wet episodes might recover carcasses previously exposed subaerially (mummified in some cases) or in litter (i.e., plant debris), whereas dry episodes are able to capture organisms produced by means of microbial mats.

Cluster analysis reveals the internal structure of the data (Table 3 and Fig. 8) segregating wet from dry cases. This result demonstrates that fossil association is sensitive to environmental conditions. Discriminant analysis (using the percentage of relative abundance for each variable) performed to classify each type of environment, yields equivalent results (Table 4). When cross-validation is carried out with respect to the discriminant predictors obtained, the fossil associations are correctly classified in $89 \%$ of cases $(95 \%$ of wet cases $\mathrm{N}=20$, and $90 \%$ of dry $\mathrm{N}=26$ are well classified). Discriminant analysis is used to confirm visually the hypothesis that there are two distinct associations, whereby the wet association is characterized by higher insect diversity plus Lepidotes fish, while the dry association typically features an abundance of "leptolepid-like" fishes and crustaceans (Fig. 9 and Table 5).

The environmental conditions in wet and dry facies associations define two distinctly biased taphofacies. There are differences in fossil abundance, richness and preservation quality. Since facies characterisation documents two ends of a spectrum of environmental conditions, a mixture of environmental conditions influencing ecological dynamics and determining the nature of the taphonomic bias is the more likely explanation. Environmental variation has a biotic response that can be read in wet and dry alternation as the dominance of one set of species over others: insects-Lepidotes-Pycnodontiform fish in wet periods and crustaceans-small basal teleosteans in dry periods. In addition, dry periods are related to periphyton dominance that affects the quality and abundance of preservation. Therefore, a sedimentological, taphonomic and palaeoecological coupling might be concluded at Las Hoyas.

\subsection{Sequence dynamics}

The succession of communities developed during an elemental sedimentary sequence (e.g. a cycle of environmental variation from wet to dry conditions in the order of $10^{3}$ years of duration, see section 5.1) has been considered as a unit, and the sequences have been comparedamong them. Three complete sequences have been defined (Fig. 4), all of which show a strong commonality in their behaviour and faunal composition. Every elemental sequence records the average features of the dominant facies association.

The first sequence is poorly characterized and incomplete. Its association is characterised by wet periods with undetermined insects and, in addition, its dry periods are far less abundant in fossil content than the equivalent dry periods of other sequences. The second and third sequences do not have different fossil assemblages, and both are dominated by the abundance and frequency of "leptolepid-like-fish" and "belostomatid insects" (Fig. 10).

The succession of elemental sequences, herein considered, do not show any superimposed trend, neither sedi- 




Fig. 8.- Hierarchical cluster of fossil association of dry (D) and wet (W) set of facies based on furthest linkage and Bray-Curtis similarity index using the PASTC program (Hammer and Harper, 2008). This method of scoring similarity was preferred over others because it satisfies those criteria that guarantee a balanced measure of similarity of species abundance (Clarke and Warwick, 2001). Before conducting the similarity test the abundance data was $\left(V_{y}\right)$ root transformed to downweight the importance of the highly abundant specimens. Case labels correspond to the sampled areas (R96, R98, NI, NS, y NSC, see Appendix 1 and Table 3). Cases are classified mainly according abundance and presence/absence of insects, fish and crustaceans (see figure 10 caption).

Fig. 8.-Aglomeración jerárquica de las asociaciones fósiles correspondientes al conjunto de facies áridas (D) y húmedas (W) obtenida con el vecino más lejano y el índice de semejanza Bray-Curtis usando el programa PASTC) (Hammer and Harper, 2008). Este método para estimar la semejanza se ha preferido por que satisface aquellos criterios que garantizan un resultado balanceado (Clarke and Warwick, 2001). Antes de realizar el test de semejanza los datos de abundancia han sido transformados $(\sqrt{ }$ y) para disminuir la importancia de los especímenes de mayor abundancia. Las etiquetas de los casos corresponden a las áreas muestreadas (R96, R98, NI, NS, y NSC, véase Apéndice 1 and Tabla 3). Los casos se han clasificado principalmente de acuerdo a la abundancia y a la presencia/ausencia de insectos, peces y crustáceos.

mentary, nor taphonomic. In other words, taphonomic structure seems to be rather monotonous or homogeneous and taphonomic gradients are repeated cyclically. Accepting the idea of a coupling between taphonomy and palaeoecology means that ecological trends on the chosen scale of analysis are also monotonous or homogeneous. The palaeoecological dynamics that arise or that can be inferred indicate an extremely stable ecological system.

There is a second hypothesis that might explain our findings, which depends on the accuracy of temporal resolution of the sedimentary record. If the resolution is assumed to be extremely near to biological timing, palaeoecological dynamics and events might be recorded with such temporal fidelity that either no significant macroeco- 


\begin{tabular}{|c|c|c|c|c|c|c|c|c|c|c|c|c|c|c|c|c|c|c|c|c|c|c|c|}
\hline SL & $\mathbf{F}$ & $\mathbf{N}$ & FI & $\mathbf{A}$ & B & C & 1 & 2 & 3 & 4 & 5 & 6 & NB & II & 7 & D & $\mathbf{E}$ & $\mathbf{F}$ & G & H & I & 8 & c \\
\hline $\mathrm{NgI02R}$ & $\mathrm{D}$ & 59 & 0 & 76.2 & 0 & 0 & 0 & 0 & 0 & 0 & 0 & 8.47 & 1.694 & 0 & 0 & 3.389 & 11.86 & 0 & 0 & 0 & 0 & 0 & 3 \\
\hline $\mathrm{NgI} 2 \mathrm{~A}$ & W & 1 & 0 & 0 & 0 & 0 & 0 & 0 & 0 & 0 & 0 & 0 & 0 & 0 & 0 & 0 & 0 & 100 & 0 & 0 & 0 & 0 & 3 \\
\hline NgI6A & W & 1 & 0 & 0 & 0 & 0 & 0 & 0 & 0 & 0 & 0 & 0 & 0 & 0 & 0 & 0 & 0 & 0 & 100 & 0 & 0 & 0 & 3 \\
\hline NgI7A & $\mathrm{W}$ & 7 & 0 & 0 & 0 & 0 & 0 & 0 & 0 & 0 & 0 & 57.14 & 0 & 0 & 0 & 14.28 & 0 & 14.28 & 0 & 0 & 0 & 0 & 3 \\
\hline NgI9A & W & 1 & 0 & 0 & 0 & 0 & 0 & 0 & 0 & 0 & 0 & 0 & 0 & 0 & 0 & 0 & 100 & 0 & 0 & 0 & 0 & 0 & 3 \\
\hline NgI10R & $\mathrm{D}$ & 47 & 0 & 2.13 & 0 & 0 & 97.87 & 0 & 0 & 0 & 0 & 0 & 0 & 0 & 0 & 0 & 0 & 0 & 0 & 0 & 0 & 0 & 2 \\
\hline NgI11R & $\mathrm{D}$ & 1 & 0 & 0 & 0 & 0 & 0 & 0 & 0 & 0 & 100 & 0 & 0 & 0 & 0 & 0 & 0 & 0 & 0 & 0 & 0 & 0 & 2 \\
\hline $\mathrm{NgI12R}$ & $\mathrm{D}$ & 31 & 0 & 25.8 & 0 & 0 & 61.2 & 0 & 0 & 0 & 0 & 0 & 0 & 3.225 & 0 & 6.451 & 3.225 & 0 & 0 & 0 & 0 & 0 & 2 \\
\hline NgI1314R & $\mathrm{D}$ & 3 & 0 & 0 & 0 & 0 & 66.6 & 0 & 0 & 0 & 0 & 0 & 0 & 33.33 & 0 & 0 & 0 & 0 & 0 & 0 & 0 & 0 & 2 \\
\hline NgI1415R & $\mathrm{D}$ & 30 & 0 & 16.6 & 0 & 3.33 & 6.66 & 0 & 0 & 3.33 & 0 & 0 & 0 & 13.33 & 0 & 0 & 0 & 0 & 0 & 0 & 0 & 0 & 2 \\
\hline $\mathrm{NgS1A}$ & $\mathrm{W}$ & 0 & 0 & 0 & 0 & 0 & 0 & 0 & 0 & 0 & 0 & 0 & 0 & 0 & 0 & 0 & 0 & 0 & 0 & 0 & 0 & 0 & 4 \\
\hline $\mathrm{NgS} 2 \mathrm{~A}$ & W & 1 & 100 & 0 & 0 & 0 & 0 & 0 & 0 & 0 & 0 & 0 & 0 & 0 & 0 & 0 & 0 & 0 & 0 & 0 & 0 & 0 & 4 \\
\hline $\mathrm{NgS} 4 \mathrm{~A}$ & $\mathrm{~W}$ & 2 & 0 & 0 & 0 & 0 & 0 & 0 & 0 & 0 & 0 & 0 & 0 & 0 & 0 & 0 & 100 & 0 & 0 & 0 & 0 & 0 & 4 \\
\hline $\mathrm{NgS5R}$ & $\mathrm{D}$ & 5 & 0 & 40 & 0 & 0 & 20 & 0 & 0 & 0 & 0 & 0 & 0 & 0 & 0 & 0 & 0 & 0 & 0 & 20 & 0 & 0 & 3 \\
\hline $\mathrm{NgS7R}$ & $\mathrm{D}$ & 3 & 0 & 0 & 0 & 0 & 0 & 0 & 0 & 0 & 0 & 0 & 0 & 66.66 & 0 & 33.33 & 0 & 0 & 0 & 0 & 0 & 0 & 3 \\
\hline $\mathrm{NgS8R}$ & $\mathrm{D}$ & 2 & 0 & 0 & 0 & 0 & 0 & 0 & 0 & 0 & 0 & 0 & 0 & 0 & 0 & 0 & 100 & 0 & 0 & 0 & 0 & 0 & 3 \\
\hline $\mathrm{NgS9R}$ & $\mathrm{D}$ & 41 & 0 & 2.43 & 0 & 0 & 2.43 & 0 & 0 & 2.44 & 0 & 4.87 & 2.43 & 2.43 & 0 & 7.31 & 46.34 & 4.87 & 2.43 & 2.43 & 4.87 & 0 & 3 \\
\hline $\mathrm{NgS1012A}$ & $\mathrm{W}$ & 3 & 33.3 & 0 & 0 & 0 & 0 & 0 & 0 & 0 & 0 & 0 & 0 & 0 & 0 & 33.33 & 0 & 0 & 33.33 & 0 & 0 & 0 & 3 \\
\hline NgS14A & W & 1 & 0 & 0 & 0 & 0 & 0 & 0 & 0 & 0 & 0 & 0 & 0 & 0 & 0 & 0 & 100 & 0 & 0 & 0 & 0 & 0 & 3 \\
\hline NSC1A & $\mathrm{W}$ & 0 & 0 & 0 & 0 & 0 & 0 & 0 & 0 & 0 & 0 & 0 & 0 & 0 & 0 & 0 & 0 & 0 & 0 & 0 & 0 & 0 & 3 \\
\hline NSC3A & W & 2 & 0 & 0 & 0 & 0 & 50 & 0 & 0 & 0 & 0 & 50 & 0 & 0 & 0 & 0 & 0 & 0 & 0 & 0 & 0 & 0 & 3 \\
\hline NSC45A & $\mathrm{W}$ & 1 & 0 & 0 & 0 & 0 & 0 & 0 & 0 & 0 & 0 & 0 & 0 & 0 & 0 & 0 & 100 & 0 & 0 & 0 & 0 & 0 & 3 \\
\hline NSC6R & $\mathrm{D}$ & 108 & 0 & 5.55 & 0 & 0 & 92.59 & 0 & 0 & 0 & 0 & 0 & 0 & 0.925 & 0 & 0 & 0 & 0 & 0 & 0 & 0 & 0.92 & 2 \\
\hline NSC7R & $\mathrm{D}$ & 22 & 0 & 18.18 & 0 & 0 & 59.09 & 0 & 0 & 0 & 0 & 0 & 0 & 0 & 0 & 9.090 & 0 & 0 & 0 & 0 & 0 & 0 & 2 \\
\hline NSC8R & $\mathrm{D}$ & 12 & 0 & 0 & 0 & 0 & 8.333 & 0 & 0 & 16.6 & 0 & 0 & 0 & 0 & 0 & 0 & 0 & 0 & 0 & 0 & 0 & 0 & 2 \\
\hline NSC910R & $\mathrm{D}$ & 51 & 0 & 3.92 & 0 & 1.960 & 7.843 & 0 & 0 & 0 & 0 & 0 & 0 & 1.960 & 0 & 1.960 & 0 & 0 & 0 & 0 & 1.960 & 0 & 2 \\
\hline NSC11A & $\mathrm{W}$ & 2 & 0 & 0 & 0 & 0 & 0 & 0 & 0 & 0 & 0 & 50 & 0 & 0 & 50 & 0 & 0 & 0 & 0 & 0 & 0 & 0 & 2 \\
\hline RS0198A & W & 4 & 0 & 0 & 0 & 0 & 0 & 0 & 0 & 0 & 0 & 25 & 0 & 0 & 0 & 0 & 50 & 25 & 0 & 0 & 0 & 0 & 2 \\
\hline RS298A & $\mathrm{W}$ & 4 & 0 & 0 & 0 & 0 & 0 & 0 & 0 & 0 & 0 & 0 & 0 & 25 & 0 & 25 & 50 & 0 & 0 & 0 & 0 & 0 & 2 \\
\hline RS3_498A & W & 0 & 0 & 0 & 0 & 0 & 0 & 0 & 0 & 0 & 0 & 0 & 0 & 0 & 0 & 0 & 0 & 0 & 0 & 0 & 0 & 0 & 2 \\
\hline RS598A & $\mathrm{W}$ & 2 & 0 & 0 & 0 & 0 & 50 & 0 & 0 & 0 & 0 & 0 & 0 & 50 & 0 & 0 & 0 & 0 & 0 & 0 & 0 & 0 & 2 \\
\hline RS698* & $\mathrm{D}$ & 1 & 0 & 0 & 0 & 0 & 0 & 0 & 0 & 0 & 0 & 0 & 0 & 0 & 0 & 0 & 0 & 0 & 0 & 0 & 0 & 0 & 1 \\
\hline RS798* & $\mathrm{D}$ & 0 & 0 & 0 & 0 & 0 & 0 & 0 & 0 & 0 & 0 & 0 & 0 & 0 & 0 & 0 & 0 & 0 & 0 & 0 & 0 & 0 & 1 \\
\hline RS1198* & $\mathrm{D}$ & 8 & 0 & 0 & 12.5 & 87.5 & 0 & 0 & 0 & 0 & 0 & 0 & 0 & 0 & 0 & 0 & 0 & 0 & 0 & 0 & 0 & 0 & 1 \\
\hline RS1398R & $\mathrm{D}$ & 8 & 0 & 0 & 25 & 37.5 & 0 & 0 & 0 & 0 & 0 & 0 & 25 & 0 & 0 & 0 & 0 & 0 & 0 & 0 & 0 & 0 & 1 \\
\hline RS1498R & $\mathrm{D}$ & 26 & 0 & 0 & 80.76 & 0 & 0 & 0 & 0 & 0 & 0 & 0 & 0 & 0 & 0 & 0 & 0 & 0 & 0 & 0 & 0 & 0 & 1 \\
\hline RS1598R & $\mathrm{D}$ & 5 & 0 & 0 & 80 & 0 & 0 & 0 & 0 & 0 & 0 & 0 & 20 & 0 & 0 & 0 & 0 & 0 & 0 & 0 & 0 & 0 & 1 \\
\hline RS1698A & W & 6 & 0 & 0 & 0 & 0 & 0 & 0 & 0 & 0 & 0 & 0 & 0 & 83.33 & 0 & 0 & 16.66 & 0 & 0 & 0 & 0 & 0 & 1 \\
\hline RS1798A & W & 29 & 0 & 10.34 & 6.89 & 0 & 6.89 & 0 & 0 & 0 & 0 & 3.44 & 0 & 31.03 & 0 & 3.44 & 20.6 & 3.44 & 0 & 3.44 & 0 & 0 & 1 \\
\hline RS1.196A & W & 9 & 0 & 0 & 11.11 & 0 & 88.8 & 0 & 0 & 0 & 0 & 0 & 0 & 0 & 0 & 0 & 0 & 0 & 0 & 0 & 0 & 0 & 3 \\
\hline RS296R & $\mathrm{D}$ & 27 & 0 & 11.11 & 3.70 & 0 & 77.7 & 0 & 0 & 0 & 0 & 0 & 0 & 0 & 0 & 0 & 0 & 0 & 0 & 0 & 0 & 0 & 3 \\
\hline RS396R & $\mathrm{D}$ & 36 & 0 & 11.11 & 16.66 & 5.55 & 58.33 & 0 & 0 & 2.77 & 0 & 0 & 0 & 5.55 & 0 & 0 & 0 & 0 & 0 & 0 & 0 & 0 & 2 \\
\hline RS496R & $\mathrm{D}$ & 29 & 0 & 31.03 & 17.24 & 10.34 & 41.37 & 0 & 0 & 0 & 0 & 0 & 0 & 0 & 0 & 0 & 0 & 0 & 0 & 0 & 0 & 0 & 2 \\
\hline RS596R & $\mathrm{D}$ & 275 & 0 & 11.63 & 1.45 & 4.72 & 75.63 & 0.36 & 0.363 & 0.72 & 0 & 0 & 0.72 & 0 & 0 & 0 & 0 & 0 & 0 & 0 & 0 & 0 & 2 \\
\hline RS696R & $\mathrm{D}$ & 6 & 0 & 33.33 & 16.66 & 0 & 33.33 & 0 & 0 & 0 & 0 & 0 & 0 & 0 & 0 & 0 & 0 & 0 & 0 & 0 & 0 & 0 & 2 \\
\hline
\end{tabular}

Table 4.- Data of the discriminant analysis. Variables are the same as Table 1, except for FI =undetermined fish. II=undetermined insects. $\mathrm{c}=$ cycles.

Tabla 4.- Datos para el análisis discriminante. Las variables son las mismas que en la Tabla 1, excepto FI y II que indican peces e insectos indeterminados, respectivamente; $\mathrm{c}=$ ciclos.

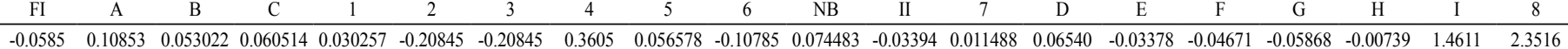

Table 5.- Discriminant Function. Function offset constant $=0.634897$. Variables are the same than in Table 4.

Tabla 5.- Función discriminante.

logical trends occurred during formation of the whole site, or the stratigraphic interval and its corresponding temporal span analyzed are not long enough to document such trends. Beyond the actual evidence, the nature of the stratigraphic record itself makes this hypothesis unreliable or extremely unlikely. The first hypothesis suggests that the evolution of these ecosystems has the ability to integrate fluctuating environmental episodes in which no successions of communities are detected. The hypothesis also supports the idea of a fairly stable (or it should be said "consistently unstable") ecological system. Those stable ecosystems might be the result of stressed environ- 

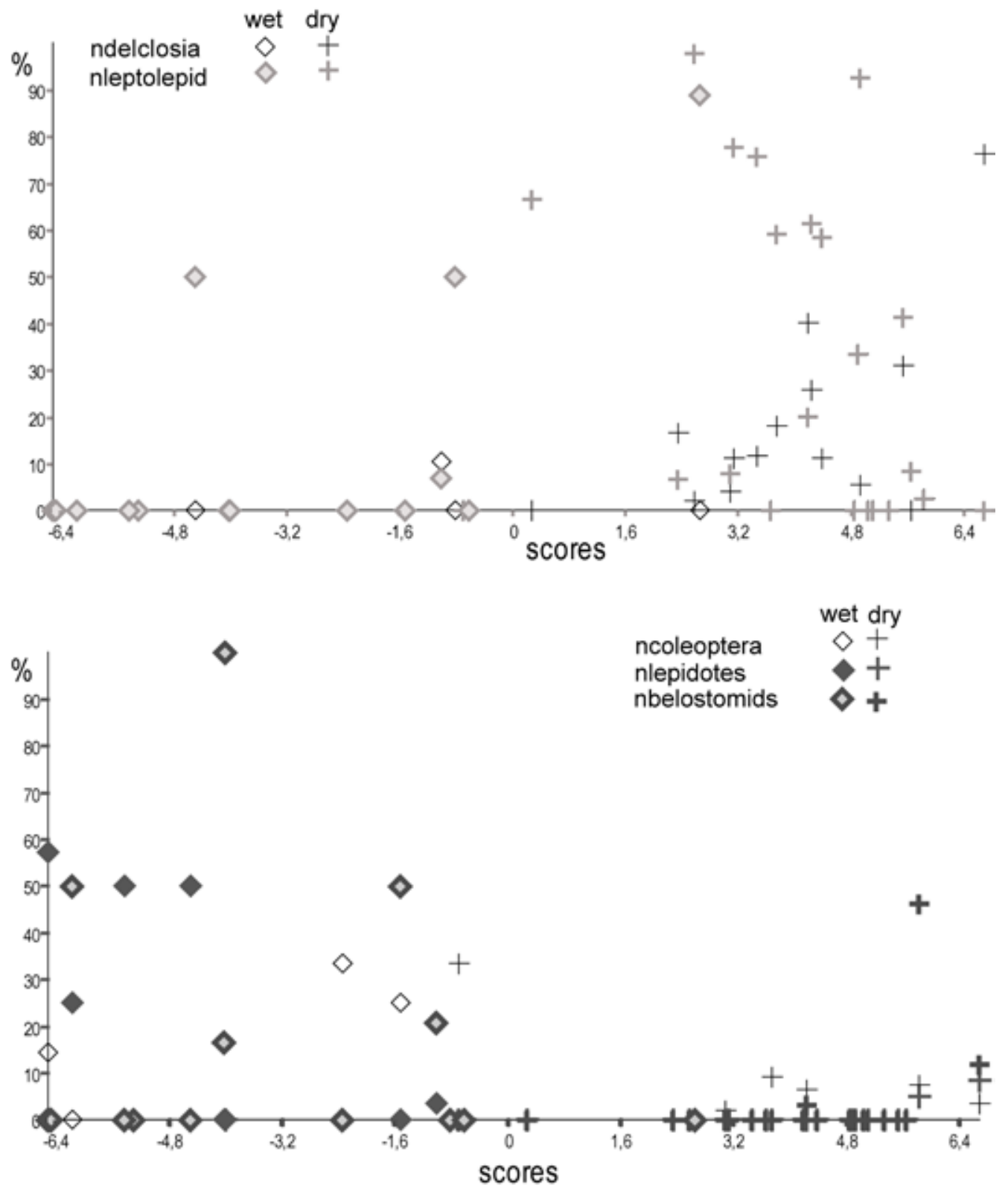

Fig. 9.- Two group discriminant analysis using PASTC program (Hammer and Harper, 2008). Discriminant function is calculated to explore how groups of facies (wet and dry) differ with respect to the fossil content. The abundance within each layer (percentage of the number of collected fossils per layer with respect to the total number of fossils) was not included in the analysis. To calculate the discriminant function, the equality of covariance matrices has been assumed. Hotelling $t$ text had a value of $\mathrm{p}=0.045$. The discrimiant function is given in Table 5. The bivariate plots represent discriminant scores (using a cutoff of zero, as the midpoint between the means of the discriminant scores of the two groups) against the percentage of the most significant variables for wet (Lepidotes fish, belostomatid and coleopteran insects) and dry ("leptolepid-like" fish, Delclosia) facies. Negative values of the discriminant scores correspond with wet facies. Wet and dry layers are indicated by diamonds and crosses, respectively.

Fig. 9.- El análisis discriminante para dos grupos se ha realizado utilizando el programa PASTC (Hammer and Harper, 2008). La función discriminante se calculó para explorar cómo los grupos de facies (húmeda y seca) difieren en su contenido fósil. La abundancia registrada en cada capa (porcentaje de fósiles recogidos por capa respecto al número total de fósiles obtenidos) no ha sido incluida en el análisis. Para el cálculo de la función discriminante, se ha asumido la igualdad en las matrices de covarianza. El valor p para el test t de Hotelling es de 0.045. La función discriminante se describe en la Tabla 5. En las gráficas bivariantes se representa las puntuaciones del discriminante (utilizando un corte en cero como punto medio entre las medias de las puntuaciones discriminantes de ambos grupos clasificados) frente al porcentaje de las variables más significativas obtenidas para el grupo húmedo (pez Lepidotes, los insectos belostomátidos y coleópteros) y para el grupo de facies secas (los peces "tipo-leptolépido", y la gamba Delclosia). Los valores negativos de las puntuaciones discriminantes corresponden a los clasificados como facies húmedas. Los símbolos utilizados en forma de diamante corresponden a facies húmedas, mientas que las cruces se refieren a las facies secas. 


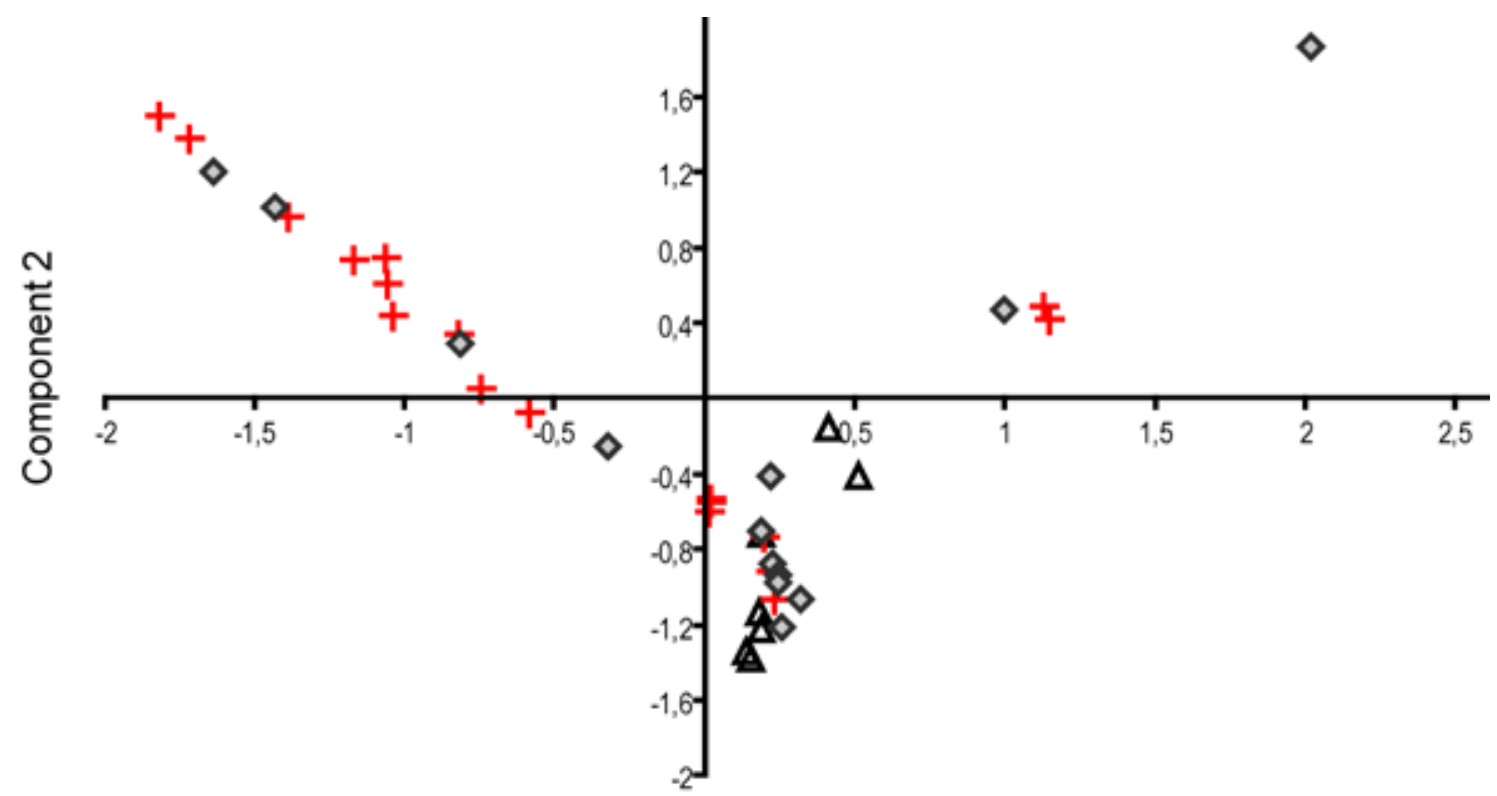

Component 1

Fig. 10.- Principal Component Analysis showing the distribution of sequences 1 to 3 . PC1 explains $31 \%$ of the variance. The major factor loadings for PC1 are "belostomatids" (towards positive values) and "leptolepid-like" (towards negative values). PC2 explains 18\% of total variance. The first, second and third sequence layers are represented by triangles, crosses and diamonds, respectively. Note that the first cycle is poorly represented and it is placed in one quadrant, while the second and the third have equivalent distributions.

Fig. 10.-Análisis de Componentes Principales mostrando la distribución de secuencias de los ciclos 1 a 3 . El 1PC explica el 31\% de la varianza. Los factores de carga principales del 1PC se refieren, a los insectos belostomátidos (positivos) y peces de tipo "leptolépidos" (negativos). El 2PC explica un 17,9\% de la varianza total. Los triángulos corresponden a las asociaciones incluidas en el primer ciclo, las cruces a las del segundo, y la forma de diamante a las del tercero. Nótese cómo el ciclo primero está peor representado y se distribuye preferentemente en el cuadrante inferior, mientras que el segundo y tercero muestra una distribución equivalente.

mental conditions, whereby the stress itself prevents the ecological climax being reached, or sustained development and evolution over time towards a new ecosystem. Palaeobiological evidence is needed to account for these stressed-stable ecosystems, wherein dramatic variations in water budget and insolation from the rainy to dry seasons cause hydrological stress, anoxia in ponds and small lakes, as well as changes in nutrient availability, biomass and diversity. In these ecosystems it would take thousands of years to reach the ecological climax.

The estimate of the possible time span represented by the sequences studied herein (each of the order of $10^{3}$ years), suggests that stability of the ecological dynamic might have been of an order of magnitude of thousands to tens of thousands of years. Whether the system was stable for the whole time span represented needs to be checked. However, not yet fully analysed data from the quarry (same facies and fossil association throughout the site) supports and predicts the long-term (tens of thousands years) stability hypothesis concerning functional relationships, whereas cases of specific taxonomic replacement are expected.

\subsection{Conclusion}

The model described above is the result of placing data from the Las Hoyas Konservat-Lagerstätte in spatial and temporal framework. This“dynamic" approach helps to reveal that the ecological reconstruction of Las Hoyas based on a "static" approach masks biases and reflect false biases. The frozen picture (that amalgamates dry and wet association) is a good representation of the palaeoecology of dry periods corresponding to the maximum abundance that should explain why some taxa are neither dominant nor ever retrieved. For instance, the scarcity and rareness of medium to large fish species might be thought to be a taphonomic bias (differential potential of preservation) linked to size. Thus, it should be expected that other large sized species were had not been preserved as well.

The dynamic approach shows that the two collections of fossil associations that are significantly coupled with facies yields two very different pictures of abundance and richness. This could imply that there were two different ecosystems or, indicate effects of a differing taphonomic bias on the same original faunal and floral structure. Ac- 
cepting the idea of a link between taphonomy, ecological composition and sedimentology (differences in the taphonomic associations and ecological composition are closely related to environmental conditions), the best supported hypothesis would be the existence of two alternating ecosystems. The ecological trends on the chosen scale of sequence analysis are also monotonous or homogeneous, as the three complete sequences delimited all show a strong commonality of behaviour and faunal composition.

Therefore, effort is required to develop methods and concepts for extracting dynamic information from the fossil record, avoiding static reconstruction wherever possible.

\section{The palaeoecological meaning of Konservat- Lagerstätten}

The study reported here has also raised some implications and new questions concerning the real meaning of Las Hoyas and other Konservat-Lagerstätten and the assumptions underpinning the concept of Konservat-Lagerstätten.

Our analysis clearly shows that this type of fossil occurrence cannot be considered as result of dramatic, unusual, sedimentary processes. The mechanisms that generated Las Hoyas are anything but dramatic events on a geological scale. Sediments and their stratigraphic arrangement are easily explained by a stratigraphic framework dominated by background sedimentation. Bacterial mats, and subordinately anoxia and rapid burial, mainly due to the fast growth of mats, account for almost all of the processes involved in the genesis of the site following the classification of Seilacher et al. (1985). Since those processes may occur over a broad spectrum of depositional environments developed at any geological time, and within sedimentary basins constrained by different climate and tectonics conditions, the model is not very specific as a predictive tool. Thus, the classification provides a collection of cases that, despite being similar in the model, are independent and lacking a common pattern of causation.

Many attempts at classifying Konservat-Lagerstätten (Briggs and Crowther, 1990) with respect to various criteria such as type of sedimentary basin, depositional system and geological age, among others, have failed to capture the actual spectrum of known lagerstätten and to give the original concept a concrete and universal meaning from a genetic, palaeoecological and palaeobiological point of view. This can be easily understood if we accept that apart from taphonomic genetic processes included in Seilacher's classification and the unusual amount of pal- aeobiological information (anatomical details, evolutionary novelties and unusual taxa) they might not share any palaeoecological commonality.

Following this line of reasoning we need to reconsider whether all those "windows" onto the fossil record are equally sized or equivalent, i.e., whether palaeoecological information, or information about taphonomic trends and other types of palaeontological information are maximized to the same extent in Konservat-Lagerstätten as the information about body fossils seems to be.

To address this issue requires every case to be reviewed in greater depth. For example, whereas Las Hoyas seems to be a clear example placed at the end of a spectrum due to its palaeontological, stratigraphic and environmental features, others can be placed within a wide scope. For instance, in Solnhofen the information about dynamic and functional palaeoecology is troublesome. Likewise, obrution Konservat-Lagerstätten linked to geological catastrophic events, such as Pompey, are severely biased by randomness. In fact, these are effectively frozen pictures of determinate ecosystems since they reflect maximum composition fidelity, and, in the case of Pompey, even great spatial fidelity (i.e., demic and autochthonous humans). In these deposits, which were produced by a "series of catastrophic events" that yielded accumulations with mass mortality (Shipman, 1975), a fine-scale census of the original biological community might be studied. In this particular case, they can be considered to be a unique taphonomic unit. Knowing the genesis of the deposit and the catastrophe the biases are under control and we would be equally justified in interpreting the taphonomic association with a static as with a dynamic approach.

Considered from this point of view, many KonservatLagerstätten might be closer to palaeontological occurrences that are not classified as Konservat-Lagerstätten as exceptional "windows" on the fossil record. Conversely, some fossil associations preserved in taphonomic environments, which result in worse preservational quality, contain better quality palaeoecological information than some Konservat-Lagerstätten. This is the case for some microfossil assemblages of La Huérguina Limestone Formation located close to Las Hoyas, whose paleoecology is similar to that revealed by the Las Hoyas analysis (Buscalioni et al., 2008). In this sense, it would be worth comparing Las Hoyas to other fossil localities with respect to their palaeogeography and age, in an attempt to determine whether they share taphonomic and palaeobiological commonalities that can contribute to our understanding of the potential megabias during the Lower Cretaceous and to contrast the dynamic hypothesis of long-term ecological stability. 


\section{Conclusions and prospects}

-Las Hoyas is a Konservat-Lagerstätten in the sense of the concept defined by Seilacher et al. (1985). Further, it can be considered a "paleoecological Lagerstätten" that holds information that, if read in its spatial and temporal framework, and by integrating stratigraphic with palaeontological information, reveals a dynamic and evolutionary ecological picture of the original ecosystem that is not available from traditional palaeocological analysis.

-Taphonomic structure of Las Hoyas Konservat-Lagerstätte is ecologically induced. The biotic response to environmental cycles induced a coupling between taphonomic and sedimentary processes that resulted in the characteristic cyclical arrangement of the stratigraphic and palaeontological record of Las Hoyas. Therefore Las Hoyas shows a significant facies bias that allows us to build a predictive model with which any newly recovered sample might be tested.

-The results of the dual approach used to reconstruct Las Hoyas ecosystem are not contradictory. Nonetheless, while the traditional approach leads to something of a dead end by providing a frozen picture of the ecosystem, the second approach moves frontiers forward, and generates new hypotheses about ecological dynamics.

-Las Hoyas was a subtropical seasonal wetland that is heavily influenced by ecological stress that impeded short-term ecological evolution and resulted in a stable ecosystem that lasted for thousands of years. The organization of the ecosystem follows a similar pattern to that of extant lentic ecosystems. It is characterized by the dominance of obligate aquatic and amphibious organisms and by the scarcity of facultative terrestrial organisms. There are multiple lines of evidence from flora and fauna of ecological strategies linked to strong seasonality and water stress. Despite the presence of shallow lakes, ecological lacustrine structures cannot be clearly recognized and Las Hoyas shows a strong bias towards wetland ecological conditions.

-The dynamic approach for the analysis of other similar preserved biotas is encouraged in order to improve the knowledge on the paleoecological meaning of Konservat-Lagerstätten.

\section{Acknowledgements}

This work is a contribution to the research project CGL-2009-11838/BTE funded by the Spanish Ministry of Science and Innovation. Excavations at Las Hoyas are funded every year by the local government of the Junta de Comunidades de Castilla-La Mancha. We thank
Fernando Escaso, curator of Las Hoyas collection, Gilberto Herrero for his skilful production of hundreds of thin sections of laminated limestones from Las Hoyas, and the many students who have participated in the fieldwork, suffering the stress of taphonomic sampling. We are grateful to all the specialists who have contributed to a better understanding of Las Hoyas diversity and whose dedication has been crucial to our synthesis. We are pleased to acknowledge Dr. Francisco José Poyato Ariza and Dr. Patrick Orr, who carefully reviewed and notably improved the original version of this manuscript. We are also delighted to acknowledge the Chinese and Japanese restaurants where, since 2003, the authors consumed tons of sushi, noodles and the waiters' patience while discussing the best way of understanding the palaeocology of Las Hoyas. Once again, Phil Mason has improved the English language of our original manuscript.

\section{References}

Allison, P. A., Briggs, D. E. G. (eds.) (1991): Taphonomy, releasing the data locked in the fossil record. Plenum Press, New York. Pp: 546.

Barral-Cuesta, A., Gomez, B. (2009): Dicot-like angiosperm leaves from the Upper Barremian of Las Hoyas (Serranía de Cuenca, Spain): morphological description and morphometrical approach. In: A. D. Buscalioni, M. Fregenal-Martinez. (eds.). Mesozoic Terrestrial Ecosystems and Biota. 10 $0^{\text {th }}$ International Meeting. Ediciones UAM, Madrid: p. 125.

Batzer, D. P., Cooper, R., Wissinger, S. A. (2006): Wetland animal ecology. In: D. P. Batzer, R. Sharitz (eds.), Ecology of Freshwater and Estuarine wetlands. University of California Press, Berkeley, Los Angeles, London: 242- 284.

Behrensmeyer, A. K., Kidwell, S. M., Gastaldo, R. A. (2000): Taphonomy and paleobiology. In: D. H. Erwin, S.L. Wing., (eds.) Deep in time.Paleobiology's perspective. The paleontological society, Supplement to volume 26 (4), USA: 103-147. http:// dx.doi.org/10.1666/0094-8373(2000)26[103:TAP]2.0.CO;2

Briggs, D. E. G. (1995): Experimental taphonomy. Palaios, 10: 539-550. http://dx.doi.org/10.2307/3515093

Briggs, D. E. G., Crowther, P. R. (1990): Taphonomy. In: D. E. G. Briggs, P. R. Crowther, (eds.) Palaeobiology. A synthesis. Blackwell Scient. Publ., Oxford: 211-303.

Briggs, D. E. G., Wilby, R., Pérez-Moreno, B. P., Sanz, J. L., Fregenal Martinez, M. (1997): The mineralization of dinosaur soft tissue in the Lower Cretaeous of Las Hoyas, Spain. Journal of the Geological Society, London, 154: 587-588. http://dx.doi. org/10.1144/gsjgs.154.4.0587

Buatois, L. A., Mángano, M. G., Fregenal-Martínez, M. A., De Gibert, J. M. (2000): Short-term colonization trace-fossil assemblages in a carbonate lacustrine konservat-lagerstätte (Las Hoyas fossil site, Lower Cretaceous, Cuenca, central Spain). Facies, 43: 145-156. http://dx.doi.org/10.1007/BF02536988

Burns, A., Walker, K. F. (2000): Biofilms as food for decapods (Atyidae, Palaemonidae) in the River Murray, Souyh Australia. Hydrobiologia, 437: 83-90. 
Buscalioni, A. D., Ortega, F., Pérez-Moreno, B. P., Evans, S. E. (1996): The Upper Jurassic Maniraptoran Theropod Lisboasaurus estesi (Guimarota, portugal) reinterpreted as a crocodylomorph. Journal of Vertebrate Paleontology, 16: 358-362. http://dx.doi.org/10.1080/02724634.1996.10011322

Buscalioni, A. D., Fregenal-Martínez, M. A. (2003): A dynamic reading of the palaeoecology of the early cretaceous continental ecosystem of Las Hoyas based on stratigraphic and taphonomic patterns. Abstracts European Palaeontological Association Workshop 2003: Exceptional Preservation, Teruel, Spain: 1516.

Buscalioni, A. D. Fregenal-Martínez, M. A., Bravo, A., Poyato Ariza, F. J., Sanchíz, B., Baez, A. M., Cambra Moo, O., MartínClosas, C., Evans, S. E., Marugán-Lobón, J. (2008): The vertebrate assemblage of Buenache de la Sierra (Upper Barremian of Serranía de Cuenca, Spain) with insights into its taphonomy and paleoecology. Cretaceous Research, 29: 687-710. http://dx.doi. org/10.1016/j.cretres.2008.02.004

Cambra-Moo, O., Buscalioni, A. D. (2003): Biostratinomic patterns in archosaur fossils: influence of morphological organization on dispersal. Journal of Taphonomy, 1: 247-268.

Clarke, K. R., Warwick, R. M. (2001). Change in marine communities; an approach to statistical analysis and interpretation. $2^{\text {nd }}$ Edition. PRIMIER-E:Plymouth

Cohen, A. S., (2003): Paleolimnology: The History and Evolution of Lake Systems. OxfordUniversity Press, Oxford: 500 p.

Daviero-Gomez, V., Gomez, B., Martín-Closas, C., Philippe, M. (2006): - Montsechia vidalii (Zeiller) Teixeira, in search of a systematic affinity. Resumé de la réunion conjointe de la Linnean Society et de l'Organisation Francophone de Paléobotanique, Montpellier, France: 8.

Evans, S. E., Milner, A. R. (1996): A metamorphosed salamander from the early Cretaceous of Las Hoyas, Spain. Phylosophical Transations Royal Society of London, 351: 627-646. http:// dx.doi.org/10.1098/rstb.1996.0061

Evans, S. E., Barbadillo, L. J. (1998): An unusaul lizard (Reptilia: Squamata) from the Early Cretaceous of Las Hoyas, Spain. Zoological Journal Linnean Society, 124: 235-265.

Fernández-López, S. (1989): La materia fósil. Una concepción dinamicista de los fósiles. En: E. Aguirre (ed.). Nuevas Tendencia en Paleontología. Consejo Superior de Investigaciones Científicas, Madrid, 10: 25-45.

Fernández-López, S. (1991): Taphonomic concepts for a theoretical Biochronology, Revista Española de Paleontología, 6: 37-49.

Fregenal-Martínez, M. A. (1998): Análisis de la cubeta sedimentaria de Las Hoyas y su entorno paleogeográfico (Cretácico Inferior, Serranía de Cuenca). Sedimentología y aspectos tafonómicos del yacimiento de Las Hoyas. Tesis Doctoral Universidad Complutense de Madrid: 354 p.

Fregenal-Martínez, M. A., Meléndez, N. (1993): Sedimentología y evolución paleogeográfica de la cubeta de Las Hoyas, Cuadernos de Geología Ibérica, 17: 231-256.

Fregenal-Martínez, M. A., Meléndez, N. (2000): The lacustrine fossiliferous deposits of the Las Hoyas sub-basin (Lower Cretaceous, Serranía de Cuenca, Iberian Ranges, Spain). In: E. H. Gierlowski-Kordesch, K. Kelts (eds.), Lake basins through space and time. AAPG Studies in Geology, 46: 303-314.

Fregenal-Martínez, M., Delclòs, X., Soriano, C. (2007): The Ba- rremian continental wetlands and lakes of the Serranía de Cuenca Basin, and their entomobiotas. In: X. Delclòs, C. Soriano (eds.), Mesozoic and Cenozoic Spanish insect localities. International Palaeoentomological Association and Diputación Foral de Álava: 48-64.

Fregenal-Martínez, M. A., Buscalioni, A. D. (2009): Las Hoyas Konservat-lagesrttätte: a fieltrip to a Barremian subtropical continental wetland ecosystem. In: L. Alcalá, R. Royo-Torres (eds.), Mesozoic Terrestrial Ecosystems in Eastern Spain. Fundamental, 14, Fundación Conjunto Paleontológico de Teruel. Dinopolis: 131-147.

Garassino, A. (1996): The macruran decapod crustaceans of the Lower Cretaceous (lower Barremian) of Las Hoyas (Cuenca, Spain). Atti. Società Italiana Science Naturale Museo Civico di Storia Naturale di Milano, 137: 101-126.

Gierlowski-Kordesch, E. H., Gómez-Fernández, J. C., Meléndez, N. (1991): Carbonate and coal deposition in an alluvial lacustrine setting: Lower Cretaceous (Weald) in the Iberian Range (East-Central Spain). In: P., Anadón, LL. Cabrera, K. Kelts (eds.), Lacustrine Facies Analysis, International Association of Sedimentologists Special Publication, 13: 111-127.

Gómez-Fernández, J. C., Meléndez-Hevia, N. (1991): Rhythmically laminated lacustrine deposits in the lower Cretaceous of la Serranía de Cuenca basin (Iberian Ranges, Spain). In: P., Anadón, LL. Cabrera, K. Kelts (eds.), Lacustrine Facies Analysis, International Association of Sedimentologists Special Publication, 13: 247-258.

Gomez, B., Martín-Closas, C., Barale, G, Solé de Porta, N., Thévenard, F., Guignard, G. (2003): Frenelopsis (Coniferales: Cheirolepidiaceae) and related male organ genera from the Lower Cretaceous of Spain. Palaeontology, 45: 997-1036.

Good, S.C. (2004): Paleoenvironmental and paleoclimatic significance of freshwater bivalves in the Upper Jurassic Morrison Formation. Sedimentary Geology, 167: 163-177. http://dx.doi. org/10.1016/j.sedgeo.2004.01.005

Gupta, N. S., Cambra-Moo, O., Briggs, D. E.K., Love, G. D., Fregenal-Martínez, M. A., Summons, R. E. (2008): Molecular taphonomy of macrofossils from the Cretaceous Las Hoyas Formation, Spain. Cretaceous Research, 29: 1-8. http://dx.doi. org/10.1016/j.cretres.2006.12.009

Haywood, A. M., Valdes, P. J., Markwick, P. J. (2004): Cretaceous (Wealden) climates: a modelling perspective. Cretaceous Research, 25: 303-311. http://dx.doi.org/10.1016/j.cretres.2004.01.005

Hammer, O., Harper, D. (2008): Paleontological data analysis. Blackwell Publishing, Oxford: 351.

Holland, S. M. (1997): Using time/environment analysis to recognize faunal events in the Upper Ordovician of the Cincinati Arch. In: C. E. Bret, G. C. Baird, (eds.), Paleontological event: stratigraphic, ecological and evolutionary implications. Columbia University Press, New York: 309-334.

Holland, S. M. (2000): The quality of the fossil record: a sequence stratigrphic perspective. In: D. H. Erwin, S. L. Wing. (eds.), Deep in time. Paleobiology's perspective. The paleontological society, Supplement to volume 26, USA: 148-168.

Iniesto, M., López-Archilla A. I., Buscalioni, A. D., Peñalver, E., Fregenal-Martínez, M. A., Guerrero, M. C.(2009): Experimental simulation of initial stages of fossilization by bacterial sealing: implications for the formation of Las Hoyas Konservat- 
Lagerstätte (Lower Cretaceous, Iberian Ranges, Spain). In: A. D. Buscalioni, M. A. Fregenal-Martínez, (eds.), Mesozoic Terrestrial Ecosystems and Biota. Abstracts $10^{\text {th }}$ International Meeting. UAM Ediciones, Madrid: p. 273.

Jaume, D. (2008): Global diversity of spelaeogriphaceans and thersbaenaceans (Crustacea; Spelaeogriphacea \& Thermobaenacea) in freshwater. Developments in Hydrobiology, 198: 219224. http://dx.doi.org/10.1007/s10750-007-9017-1

Kidwell, S. M. (1991): The stratigraphy of shell concentrations. In: P. A. Allison, D. E. G. Briggs, (eds.), Taphonomy, releasing the data locked in the fossil record. Plenum Press, New York: 211-290.

Kidwell, S. M. (1993): Taphonomic expressions of sedimentary hiatus: field observations on bioclastic concentrations and sequence anatomy in low, moderate and high subsidence settings. Geologische Rundschau, 82: 189-202. http://dx.doi. org/10.1007/BF00191825

Martín-Closas, C. (2005): El paisaje vegetal del Cretácico inferior de la Cordillera Ibérica. En: G. Meléndez, M. Morero-Azanza (eds.), La vida y los ambientes sedimentarios en el Periodo Cretácico. Publicaciones del Seminario de Paleontología de Zaragoza, 7: 49-61.

Martín-Closas, C., Dieguez, C. (1998): Charophytes from the Lower Cretaceous of the Iberian ranges, Spain. Palaeontology, 41: 1133-1152.

Martín-Closas, C., Gomez, B. (2004): Taphonomie des plantes et interprétations paléoécologiques. Une synthèse. Geobios, 37: 65-88.

Martín-Closas, C., Martínez-Delclòs, X., Buscalioni, A. D., De La Fuente, M., Fregenal-Martínez, M. A., Gómez, B., PoyatoAriza, F. J., Soriano, C. (2003): Preservation bias in the Aquatic Ecosystem of "Las Hoyas" (Late Barremian, Spain). In: L. Alcalá (ed.), Abstracts European Palaeontological Association Workshop 2003: Exceptional Preservation, Teruel, Spain: 67-68.

Martínez-Delclòs, X. (1991): Insects from the lithographical limestones of the Serra del Montsec. Lower Cretaceous of Catalonia, Spain. In: X. Martínez-Delclòs (ed.), The Lower Cretaceous Lithographic limestones of Montsec (Catalonia, Spain): 10 years of Paleontological Expeditions, Institut d'Estudis Ilerdencs, Lleida: 61-71.

Martínez-Delclòs, X. (1993): Blátidos (Insecta Blattodea) del Cretácico inferior de España. Familias Mesoblattinidae, Blattulidae y Poliphagidae. Boletín Geológico y Minero de España, 104: 516-538.

Martínez-Delclós, X., Nel, A., Popov, Y. A. (1995): Systematic and functional morphology of Iberonepa romerali $\mathrm{n}$. Gen. N. Sp. Belostomatidae, Stygeonepidae from the Spanish Lower Cretaceous (Insecta, Heteroptera, Neopomorpha). Journal of Paleontology, 69: 469-508.

Martínez-Delclòs, X., Briggs, D. E. G., Peñalver, E. (2004): Taphonomy of insects in carbonates and amber. Palaeogeography, Palaeoclimatology, Palaeoecology, 203: 19-64.

Mas, J. R., Alonso, A., Meléndez, N. (1982): El Cretácico basal "Weald" de la Cordillera Ibérica Suroccidental (NW de la provincia de Valencia y E de la de Cuenca). Cuadernos de Geología Ibérica, 8: 309-335.

McGowan, G., Evans, S.E. (1995): Albanerpetontid amphibians from the Cretaceous of Spain. Nature, 373: 143-145. http:// dx.doi.org/10.1038/373143a0
Mendelssohn, I. A., Batzer, D. P. (2006): Abiotic constraints for wetland plants and animals. In: D. P. Bazter, R. Sharitz (eds.), Ecology of Freshwater and Estuarine wetlands. University of California Press, Berkeley, Los Angeles, London: 82-114.

Ortega, F. (2004): Historia Evolutiva de los cocodrilos Mesoeucrocodylia. Tesis Doctoral, Universidad Autónoma de Madrid. Facultad de Ciencias: 350 pp.

Ortega, F., Sanz, J. L., Barbadillo, J. L., Buscalioni, A. D., Diéguez, C., Evans, S. E., Fregenal-Martinez, M. A., De la Fuente, M., Madero, J., Martín-Closas, C., Martinez-Delclós, X., Meléndez, N., Moratalla, J. J., Pérez-Moreno, B. P., Pinardo-Moya, E., PoyatoAriza, F. J., Rodriguez-Lázaro, J., Sanchiz, B., Wenz, S. (1999): El yacimiento de Las Hoyas (La Cierva, Cuenca): Un KonservatLagerstätte del Cretácico inferior. Patrimonio Historico Arqueologia Castilla-La Mancha. In: E. Aguirre, I. Rabano (coord. ) La Huella del pasado. Fósiles de Castilla-La Mancha, Comunidad de Castilla- La Mancha: 195-216.

Ortega, F., Buscalioni, A. D., Delclòs, X., Fregenal-Martínez, M. A., Martín-Closas, C., Poyato-Ariza, F. J., Sanz, J. L., Soriano, C. (2003): Los fósiles del Cretácico de Las Hoyas: un yacimiento excepcional. In: R. Nuche del Rivero (ed.), Patrimonio Geológico de Castilla- La Mancha. Enresa, Madrid: 422-448.

Palci, A., Jurkovsek, B., Kolar-Jurkovsek, T., Cadwell, M. W. (2008): New palaeoenvironmental model for the Komen (Slovenia) Cenomanian (Upper Cretaceous) fossil lagerstätte. Cretaceous Research, 29: 316-328. http://dx.doi.org/10.1016/j. cretres.2007.05.003

Pérez-Moreno, B. P., Sanz, J. L., Buscalioni, A. D., Moratalla, J. J., Ortega, F., Rasskin-Gutman, D. (1994): A unique multitoothed ornithomimosaur from the Lower Cretaceous of Spain. Nature, 30: 363-367. http://dx.doi.org/10.1038/370363a0

Ponomarenko, A., Martínez-Delclòs, X. (2000): New beetles (Insecta: Coleoptera) from the Lower Cretaceous of Spain. Acta Geologica Hispanica, 35: 47-52.

Poyato-Ariza, F. J. (1997): A new assemblage of Spanish Early Cretaceous teleostean fishes, formerly considered "leptolepids": phylogenetic relevance. Comptes Rendus de l'Académie des Sciences - Series IIA - Earth and Planetary Science, 325: 373379.

Poyato-Ariza, F. J. (2003): Dental characters and phylogeny of pycnodontiform fishes. Journal of Vertebrate Paleontology, 23: $937-$ 940. http://dx.doi.org/10.1671/17

Poyato-Ariza, F. J. (2005): Palaeoecology of the fishes from the Early Cretaceous lake of Las Hoyas, Cuenca, Spain, with a hypothesis of sexual dimorphism for the chanidae Rubiesichthys. Bulletin of the Kitakyushu Museum of Natural History and Human History series A, Natural History), 3: 153-168.

Poyato-Ariza, F. J., Wenz, S. (2004): The new pycnodontid fish genus Turbomesodon, and a revision of Macromesodon based on Lower Cretaceous new material from Las Hoyas, Cuenca, Spain. In: G. Arratia, A. Tintori (eds.), Mesozoic Fishes 3: Systematics, Palaeoenvironment and Biodiversity. München Verlag Dr. Pfeil: 341-378.

Poyato-Ariza, F. J., Talbot, M. R., Fregenal-Martínez, M. A., Meléndez, N., Wenz, S. (1998): First isotopic and multidisciplinary evidence for nonmarine coelacanths and pycnodontiform fishes: palaeoenvironmental implications. Palaeogeography, $\mathrm{Pa}$ laeoclimatology, Palaeoecology, 144: 64-84.

Rabadà i Vives, D. (1991): Crustáceos Decápodos de las Calizas 
Litográficas del Cretácico Inferior de España: las Hoyas (Cuenca) y el Montsec de Rúbies (Lleida), Universitat de Barcelona: Barcelona. $184 \mathrm{p}$.

Rabadà, D. (1993): Crustáceos decápodos lacustres de las calizas litográficas del Cretácico Inferior de España. Cuadernos de Geología Ibérica, 17: 345-370.

Salas, R., Casas, A. (1993): Mesozoic extensional tectonics, stratigraphy and crustal evolution during the Alpine cycle of the eastern Iberian basin. Tectonophysics, 228: 33-55. http://dx.doi. org/10.1016/0040-1951(93)90213-4

Sanz, J. L., Chiappe, L. M., Pérez-Moreno, B. P., Buscalioni, A. D., Moratalla, J. J., Ortega, F., Poyato-Ariza, F. J. (1996): An Early Cretaceous bird from Spain and its implications for the evolution of avian flight. Nature, 382: 442-445. http://dx.doi. org/10.1038/382442a0

Sanz, J. L., Diéguez, C., Poyato-Ariza, F. J. (2000): Die UnterKreide von Las Hoyas, Cuenca, Spanien. In: G. Pinna (coord.) Europäische Fossillagerstätten. Springer-Verlag Berling Heidelberg: 155-160.

Sanz, J. L., Fregenal-Martínez, M. A., Meléndez, N., Ortega, F. (2001): Las Hoyas. In: D. E. G. Briggs, P. R. Crowther (eds.) Palaeobiology II. Blackwell Science, Oxford: 356-359.

Sanz, J. L., Pérez-Moreno, B. P., Chiappe, L. M., Buscalioni, A. D. (2002): The birds from the Lower Cretaceous of Las Hoyas (Province of Cuenca, Spain). In: L. M. Chiappe, L. M. Witmer (eds.) Mesozoic Birds. University of California Press: 209-229.

Seilacher, A. (1990): Taphonomy of Fossil-Lagerstätten: an overview. In: D. E. G. Briggs, P. Crowther (eds.), Paleobiology. Blackwell Science, Oxford: 266-270.

Seilacher, A., Reif, W. E., Westphal, F. (1985): Sedimentological, ecological and temporal patterns of fossil lagerstatten. Phylosophical Transactions of the Royal Soc. London B, 311: 5-23. http://dx.doi.org/10.1098/rstb.1985.0134

Selden, P., Penney, D. (2003): Lower Cretaceous spiders (Arthropoda: Arachnida: Araneae) from Spain. Neues Jahrbuch fur Geologie und Paläontologie, Abhandlungen, 2003: 175-192.

Shipman, P. (1975): Implications of drought for vertebrate fossil assemblages. Nature, 257: 667-668. http://dx.doi. org/10.1038/257667a0

Soria, A. R., Meléndez, A., Aurell, M., Liesa, C. L., Meléndez, M. N., Gómez-Fernández, J. C. (2000): The Early Cretaceous of the Iberian Basin (Northeastern Spain). In: In: E. H. GierlowskiKordesch, K. Kelts (eds.), Lake basins through space and time. AAPG Studies in Geology, 46: 257-262.

Soriano, C. (2006): Paleobiología de los coleópteros del Cretácico inferior español. Tesis Doctoral. Universitat de Barcelona. $345 \mathrm{pp}$.

Soriano, C., Delclós, X. (2006): New cupedid beetles from the Lower Cretaceous of Spain and the palaeogeography of the family. Acta Paleontologica Polonica, 51: 185-200.
Soriano, C., Kirejtshuk, A. G., Delclòs, X. (2006): The Mesozoic Laurasian family Parandrexidae (Insecta: Coleoptera), new species from the Lower Cretaceous of Spain. Comptes Rendus Palevol, 5: 779-784. http://dx.doi.org/10.1016/j.crpv.2006.03.006

Soriano, C., Ponomarenko, A., Delclòs, X. (2007): Coptoclavid beetles (Coleoptera: Adephaga) from theLower Cretaceous of Spain: A new feeding strategy in beetles. Palaeontology, 50: 1-12. http://dx.doi.org/10.1111/j.1475-4983.2007.00642.x

Stinnesbeck, W., Ifrim, C., Schmidt, H., Rindfleisch, A., Buchy, M-C., Frey, E., Gonzalez-Gonzalez, A-H., Vega, F. J., Cavin, L., Keller, G., Smith, K. T. (2005): A new lithographic deposit in the Upper Cretaceous Austin Group at El Rosario, county of Müzquiz, Coahuila, northeaster México. Revista Mexicana de Ciencias Geológicas, 22: 401-418.

Talbot, M. R., Meléndez, N., Fregenal-Martínez, M. A. (1995): The waters of the Las Hoyas lake: Sources and limnological characteristics. In: N. Meléndez (ed.), Las Hoyas. A lacustrine Konservat-Lagerstätte, Cuenca, Spain. Universidad Complutense, Madrid: 11-16.

Van der Valks, A.G. (2006): The Biology of freshwater wetlands. Oxford University Press: $173 \mathrm{p}$.

Vilas, L., Mas, R., García, A., Arias, C., Alonso, A., Meléndez, N., Rincón, R. with the collaboration of Elizaga, E., FernándezCalvo, C., Gutiérrez, C., Meléndez, F. (1982): Ibérica Suroccidental. In: El Cretácico de España. Editorial de la Universidad Complutense de Madrid: 457-513.

Vilas, L., Alonso, A., Arias, C., Mas, R. Rincón, R., Meléndez, N. (1983): The Cretaceous of the Southwestern Iberian Ranges (Spain). Zitteliana, 10: 245254.

Vullo, R., Buscalioni, A. D., Marugán-Lobón, J., Moratalla, J. J. (2009): Pterosaur remains from the Early Cretaceous Lagerstätte of Las Hoyas, Spain: palaeoecological significance. Geological Magazine, 146: 931-936. http://dx.doi.org/10.1017/ $\underline{\mathrm{S} 0016756809990525}$

Wenz, S.,Poyato-Ariza, F.(1994): Les Actinoptérygiens juvéniles du Crétacé inférieur du Montsec et de Las Hoyas (Espagne). Geobios Mémoire spécial, 16: 203-212. http://dx.doi.org/10.1016/ S0016-6995(94)80035-9

Zherikhin, V. V., Gratshev, V. G. (2003): A New Weevil-Beetle (Insecta, Coleoptera, Nemonychidae) from the Lower Cretaceous of Spain. Paleontological Journal, 37: 407-408.

Ziegler, A. M., Barret, S. F., Scotese, C. R. (1983): Mesozoic and Cenozoic paleogeographic maps. In: P. Brosche, J. Sundermann (eds.), Tidal Friction and the Earth's Rotation, II. Springer-Verlag, Berlín: 240-252.

Ziegler, A. M., Raymond, A. L., Gierlowski, T. C., Horrell, M. A., Rowley, D. B., Lottes, A. L. (1987): Coal, climate and terrestrial productivity: the present and Early Cretaceous compared. In: A. C. Scott (ed.), Coal and Coal-bearing Strata: Recent Advances. Geological Society of London Special Publications, 32: 25-49. http://dx.doi.org/10.1144/GSL.SP.1987.032.01.04 


\section{Appendix}

Data. Raw data were obtained by sampling the fossil association layer-by-layer (Table 1). Each sampling area is denoted by a colour: pink 1996 (Rosa 96), pink 1998 (Rosa 98), lower black (Negra I, inferior), upper black (Negra S, superior), and lowermost black (Negra S/C). The layer itself is herein named in Spanish as capa and numbered (0 or 0.1, 0.2, 1, 2, etc.). Since the objective is to test the taphonomic association for each facies type, the layers have been grouped accordingly. For instance, NegraIcapa 02 to NegraScapa from layers 5 to 9 correspond with dry facies. The table below summarizes the total number of fossils found according the above variables and the groups formed by the layers, by facies types (dry or wet).

\begin{tabular}{lcc} 
Groups of layers- & Facies types & $\begin{array}{c}\text { Number of fossils } \\
\text { in association }\end{array}$ \\
\hline NegraIcapa02NegraScapa5-9 & Dry & 110 \\
NegraIcapa2-NegraIcapa9 & Wet & 10 \\
NegraIcapa10-NegraIcapa15 & Dry & 112 \\
NegraScapa1-NegraScapa4 & Wet & 3 \\
NegraScapa5-NegraScapa9 & Dry & 51 \\
NegraScapa10NegraScapa14 & Wet & 4 \\
NegraS/Ccapa1-NegraS/Ccapa5 & Wet & 3 \\
NegraS/Ccapa6-NegraS/Ccapa10 & Dry & 193 \\
NegraS/Ccapa11 & Wet & 2 \\
Rosa98capa01Rosa98capa5 & Wet & 10 \\
Rosa98capa6Rosa98capa15 & Dry & 48 \\
Rosa98capa16Rosa98capa17 & Wet & 35 \\
Rosa96capa 1.1 & Wet & 9 \\
Rosa96capa2Rosa96capa6 & Dry & 373 \\
\hline
\end{tabular}

